\title{
Why Did Pre-Modern States Adopt Big-God Religions?*
}

\author{
By \\ Stergios Skaperdas \\ Department of Economics \\ University of California, Irvine \\ Irvine, CA 92697 \\ USA \\ and \\ Samarth Vaidya \\ Department of Economics \\ Deakin Business School \\ Deakin University, Geelong, VIC 3220, Australia \\ Revised on June 11, 2019
}

\begin{abstract}
Over the past two millennia successful pre-modern states in Eurasia adopted and cultivated Big-God religions that emphasize (i) the ruler's legitimacy as divinely ordained and (ii) a morality adapted for large-scale societies that can have positive economic effects. We make sense of this development by building on previous research that has conceptualized pre-modern states as maximizing the ruler's profit. We model the interaction of rulers and subjects who have both material and psychological payoffs, the latter emanating from religious identity. Overall, religion reduces the cost of controlling subjects through the threat of violence, increases production, increases tax revenue, and reduces banditry. A Big-God ruler, who is also a believer, has greater incentives to invest in expanding the number of believers and the intensity of belief, as well as investing in state capacity. Furthermore, such investments are often complementary, mutually reinforcing one another, thus leading to an evolutionary advantage of rulers that adopted Big-God religions.
\end{abstract}

JEL: D70, H0, N40, P40, Z1

Keywords: State, ruler, anarchy, religion, morality, legitimacy, state capacity.

\footnotetext{
*For useful conversations and advice on the earlier version of the paper titled "For-Profit States and Big Gods" we would like to thank Alina Arseniev-Koehler, Renaud Bellais, Dan Bogart, Rob Boyd, Jean-Paul Carvalho, Metin Cosgel, Larry Iannaccone, Mike McBride, Eleni Skaperdas, and participants at the ASREC conference in Boston in March 2019, a brown bag presentation at Chapman University, and the conference on the predatory state at University of Paris 13 . Two anonymous referees provided extensive comments that helped us significantly improve our argument.
} 


\section{Introduction}

After the conversion of Roman Emperor Constantine in the early fourth century CE, Christianity spread through Europe so that a millennium later no single ruler of note was a heathen. Similarly, Islam was adopted by all rulers in large parts of Asia and North Africa. Even Judaism, not known for its missionary zeal, was apparently adopted by Khazaria's ruling elite in the eighth century. Later, of course, these religions spread to most other parts of the world. Even states that did not adopt monotheistic religions - such as China and states in South and Southeast Asia - encouraged and emphasized religious practices that have some important similar effects as monotheism - notions of salvation, morality, and duty adapted for large-scale societies.

A main characteristic of such religions is that they have Big Gods (a term introduced by Norenzayan 2013) who can be all-knowing and monitor behavior 24 hours a day, seven days a week. Big Gods don't have to be single gods but they are "moralizing" gods who engage in continuous supernatural monitoring in ways that individuals cannot hide from. They can thus influence a person's rewards and punishment in life and afterlife alike by having a total view of a person's behavior. A Big God does not just have partial snippets of the person's behavior who could hide some unbecoming facts and acts as they could do from a "small god." 1

What accounts for the apparent advantage of rulers who adopted and cultivated such religions? We argue that Big-God religions and ideological frames confer at least two advantages. First, a Big God confers streamlined and direct legitimacy and status to the ruler as he confers "the Mandate of Heaven" or "there is a single God and his representative on earth is the King." The ruler's subjects can even identify psychologically with the ruler and "give Caesar what belongs to Caesar." ${ }^{2}$

Second, Big-God religions encourage moral behavior and contribute to large-scale society cooperation. A Big God is all-knowing and monitors behavior continuously, even though he might not even need to do so when morality and a sense of guilt are sufficiently internalized by individual believers. Big-God religions encourage moral behavior that contributes to contract enforcement and large-society economic exchange - "watched people are nice people" as stated by Norenzayan (2013, p.54).

These two functions of Big-God religion - the legitimating and the moralizing ones - have been identified by several literatures separately but, to our knowledge, they have not been studied together, as contributing to the evolution of Eurasian states over the past two millennia. On

\footnotetext{
${ }^{1}$ Reincarnation, for example, implies continuous supernatural monitoring, for it would be difficult to avoid and allow a person to sneak in bad acts so that such bad acts could be avoided in the eventual accounting of a person's lifetime.

${ }^{2}$ There is a long debate about the meaning of the phrase and its surrounding text in the New Testament that partly revolves around its meaning about the separation of Church and State. That does not concern us here. The phrase itself implies the legitimacy and the right of the ruler to taxes regardless of the degree of separation between Church and State. In cases of severe conflict, such as the ones that led to the Reformation, Protestant rulers typically brought the new churches under the ruler's close control such as the Anglican Church. For an economic analysis of the Medieval Church as a firm, see Ekelund et al. (1996).
} 
the one hand, social scientists and historians have long noted the legitimating role of "historic" religions (see, for example, Finer 1997, p. 614). Cosgel and Miceli (2009) and Cosgel et al. (2018) incorporate the role of religion in legitimating or deligitimating a ruler and easing or impeding tax collection. On the other hand, evolutionary anthropologists, psychologists, and experimental economists have identified and attempted to refine how members of large-scale societies tend to have a different type of morality than those of small-scale societies, with the former better adapted for more complex economies (e.g., Henrich et al. 2001; Norenzayan 2013).

These advantages can translate into greater than otherwise revenue and profits for the ruler. At high levels of belief, Big God's monitoring and greater moral behavior of his subjects reduce the ruler's costs in providing internal security against banditry and common crime. Moreover, moral behavior facilitates economic exchange and increases overall economic activity. The legitimacy and status of the ruler reduces his subjects' resistance, and his cost of taxation. Investing in Big God and turning almost all subjects to believers is also a profit-maximizing strategy for the ruler. This is especially the case, as we show, when the rule is a believer himself or herself.

We examine these effects of Big-God religion within a model in which rulers first maximize their profit, the difference between tax revenue and the cost of running the state. This is an approach used by a number of economists and other social scientists in thinking and modeling pre-modern states. $^{3}$ In all of the existing models the payoffs of rulers and subjects are material payoffs. To account for the effects of religion, we introduce psychological payoffs in subjects as well as rulers in accordance with evidence in the psychological literature (Tajfel 1981) and applications in modeling identity in individual behavior and game-theoretic models (see Kalin and Sambanis 2018, for a recent review).

In the next section we briefly discuss the historical context of Big-God religions, their adoption by states, and the possibility of introducing psychological payoffs in economic, rational-choice models.

We then examine a setting without a state - anarchy - in which the population sorts itself between producers and bandits in the presence of both believers and heathens, the former paying a psychological penalty for being bandits. Producers engage in both self-protection and production. From an economic viewpoint in this setting it is better to have a greater fraction of the population become producers and have the producers devote fewer resources to self-protection. As the fraction of believers increases we find a step-wise increase in the number of producers. Thus, morality of believers by itself can increase total production even though individualized self-protection is not as efficient as more collective types of security.

In the subsequent three sections we introduce and examine a ruler who provides security as a

\footnotetext{
${ }^{3}$ They include Levi (1988), Engineer (1989), Findlay (1990, 1996), Olson (1993), Grossman and Noh (1994), McGuire and Olson (1996), Robinson (1997), Konrad and Skaperdas (1998, 2007, 2012), Wintrobe (1998), Skaperdas (2001, 2014), Moselle and Polak (2001), Myerson (2008), North, Wallis, and Weingast (2009), Leeson (2014), and Vahabi (2016a, 2016b).
} 
public good but also uses the input for the public good - guards who are specialists in violence to extract revenue from producers. Thus, producers devote resources to self-protection to reduce the ruler's taxation as well as against bandits. Believer producers value the status and prestige of the ruler and devote, relative to heathen producers, fewer resources to self-protection and more to production. A Big-God ruler has higher profits than a heathen ruler at low enough and high enough fraction of believers. At low fractions of believers there is no benefit of having higher number of producers than otherwise and the profit to the ruler comes solely from the lower compensation that he has to pay to guards who are believers rather than heathens. This possibly represents the early phase of the expansion of Big-God religions that are confined to the elites and their immediate subordinates. At intermediate levels of believers, the ruler's material profits are actually gradually decreasing in the fraction of believers because all new believers become producers who are more vulnerable to heathen bandits than heathen producers are. At higher fractions of believers, the ruler's material profits are strongly increasing and then stay at a high level. The higher levels of profit at high enough levels of religiosity is due to the higher taxes received from believer producers, the higher fraction of believers who become producers, as well as the lower level of wages paid to believer guards.

The question that emerges, then, is that if we were to consider solely the material profits of the ruler there would be no incentive on the ruler's part to encourage religiosity at intermediate levels of believers. This can change, however, if the ruler himself were to be a believer who values the degree of religiosity, both the extent of belief and its intensity. Then, the ruler's total payoff that includes both material and psychological components is everywhere increasing in the number of believers in the population as well as the intensity of their belief.

We then analyze the incentives for a ruler to invest in converting the population to believers and in intensifying moral beliefs and enhancing his own status and legitimacy; that is, we examine the incentives for a ruler to invest in temples, churches, or mosques, in priests, or in regularized rituals. At lower and intermediate levels of the number of believers, we find complementarity between the incentives to invest in conversion and in enhancing the ruler's legitimacy. Moreover, we find these investments to also be complementary with investing in state capacity, the ability of the state to provide collective security more effectively as well as its capacity to extract revenues (for research on the topic, see Besley and Persson 2011, McBride et al. 2011, or Johnson and Koyama 2017). When the number of believers is high enough, the marginal benefit of investing in morality can be highest under certain conditions.

Thus, the various components of religious investments - on conversion, on morality, on legitimacy - appear to co-evolve with one another as well as with state capacity, albeit differently across different levels of religiosity. The higher incentives to invest in morality when the number of believers is high appear consistent with the recent empirical findings of Whitehouse et al. (2019) who argue that "moralizing" gods typically follow by centuries a society's measured level of complexity, but 
one would need to look closer to the underlying data to make a better informed determination about that. ${ }^{4}$ More generally, the fact that Big-God religions that were adopted by Eurasian rulers have multiple tendencies - the tendency to seek converts, to emphasize ruler legitimacy and largesociety morality as well as their complementarity with building greater state capacity - indicate that Big-God religions have a "package" of attributes. While a single component of the package might not confer a clear advantage to rulers, the whole of it is more likely to be successful in the long-run and the reason that rulers who adopted such packages tended to survive more than those who did not.

\section{Empires, religion and individual psychology}

There are two main instruments for rulers to gain, maintain, and enhance their power: The Sword and the Word; violence (and the threat of violence) and persuasion. The latter includes ideologies and religion that could be considered forms of congealed persuasion, the accumulated arguments and understandings from the past that help people make sense of their world.

The rulers of the earliest empires that appeared in Eurasia and Egypt were likely using persuasion mechanisms to enhance their legitimacy and for their populations to identify with their rule. Although the evidence is thin on that dimension it does point to a gradual movement from high reliance on brute force (the Hittite empire) to greater dependence on the status or prestige of the ruler. ${ }^{5}$ The Assyrian empire and then even more so the Achaemenid Persian empire, for example, appeared to use a "softer touch." Yet, early forms of Big moralizing Gods do not appear to have penetrated the beliefs of the masses. Zoroastrianism, for instance, was an early form of monotheism that was adopted by the Persian empire but was essentially a religion of the elites, although it was effective in securing easier tribute collection through the legitimacy and prestige of its rulers. ${ }^{6}$

The available evidence points as well to a gradual emergence and spread of morality and prosociality fit for larger societies. Norenzayan (2013, Ch. 7) surveys the historical and other evidence. ${ }^{7}$ Ritual and constant visual reminders (for example, houses of worship) that enhance the ruler's prestige and legitimacy and increase moral conformity spread over the past two millennia with

\footnotetext{
${ }^{4}$ Whitehouse et al. (2019) show how their measure of society's complexity typically precedes their measures of "moralizing high gods" or of "broad supernatural punishment." While their measure of society's complexity appears to be "polity population" and it is shown to be highly correlated with other measures, they don't appear to focus on the role of rulers and the state as much as we do in this paper. Nevertheless, their data could possibly be adapted and used to examine empirical hypotheses that emerge from our paper.

${ }^{5}$ Finer (1997), Mann (1986), Dudley (1991), and Cunliffe (2017) provide overviews and evidence on early empires.

${ }^{6}$ See Holland (2005, Ch.2). The Zoroastrian Big God - Ahura Mazda - was also used by Darius to legitimate his usurpation of power and his acceptance by Persian elites. However, Darius and other Persian kings were very tolerant of other gods in their vast empire. One difference with many of the subsequent states that adopted Big Gods was the intolerance towards lesser gods or, in some cases, of other Big-God religions.

${ }^{7}$ Evidence includes game experiments in different types of societies, including hunter-gatherers. For example, Henrich et al. (2001) have found that individuals from less complex societies behave in a less pro-social fashion in ultimatum, public-good, and dictator games.
} 
the active help of rulers. Big Gods intensified the monitoring and the discipline with which large populations shared common norms and abided by them.

Associated with the spread of a new individual morality is the "spiritual and intellectual awakening" that occurred almost simultaneously across Eurasia during the Axial Age, around the fifth and fourth centuries BCE (Jaspers 2011[1949]). From Plato and Socrates in Greece, to the Buddha in India, to Confucius in China, philosophies, ideologies, and religions were articulated that emphasized what we now consider as self-evident individual morality in large-scale societies. The ideas and thoughts took centuries and millennia to spread to the nooks and crannies of societies around the world. Rulers picked up on the great thinkers and started propagating their thoughts, but of course with twists that could be considered self-interested on their part. Confucius' thought, for instance, was adopted by many Chinese Warring states rulers and by the Han emperors afterwards, but with an emphasis on social hierarchy that has been argued did not exist in Confucius' thought itself (Creel 1949).

From an economic, rational-choice perspective, the two effects of Big-God religion that we examine - the enhancement of ruler's legitimacy and the spread of morality - work themselves through individual psychological payoffs. These payoffs are part of the identities of individuals as first argued within economics by Akerlof and Kranton (2000). We employ the particular modeling approach, based on the psychological literature (such as Tajfel 1981), that has been used to model social identities in modern times (e.g., Shayo 2009, Sambanis and Shayo 2013, and Sambanis et al. 2015).

The model and approach are also consistent with those of the economics of religion literature (see Iannaccone 1998, and Iyer 2016, for overviews). If anything, especially compared to models that are intended to explain specific aspects of modern religious behavior, ours is too simple (or even too simplistic) but this has to be necessarily so for tractability as we intend to understand a long-run macro-historical phenomenon that involves multiple actors. One particular study that complements our approach is that of Raskovich (1996) who provides an intriguing industrialorganization perspective on the emergence of Yahweh as a single God out of multiple pagan cults and gods, partly encouraged by Israelite kings such as David for political reasons.

What we do not consider in this paper explicitly is the military competition between rulers that has been historically important. Nevertheless our findings inform long-run patterns of Eurasia's history. For a state to survive it had to be able to defend itself against other states, especially heathen ones. The gradual conversion or conquest of heathen rulers by Big-God ones appears to have been the long-run outcome over the past two millennia (and before modern times). In the meantime, there were plenty of heathen rulers and states that invaded and subjugated Big-God rulers and states. Goth, Frank, and other Germanic rulers invaded a weak Roman Empire that was in the process of Christianization before the rulers themselves converted to Christianity. Similar trajectories were followed by Viking and Slavic rulers raiding and even conquering Christian states 
before themselves becoming converts. Huns, Mongols, and Turks raided almost all of Eurasia and conquered a big chunk of it but they did not establish lasting states until they converted to Islam themselves. Likewise, the last imperial dynasty of China that lasted for almost three centuries was created by steppe conquerors, the Qing/Manchus, who kept and adopted traditional Chinese culture, religious practices, and statecraft.

There were also many cases in which the heathens were repelled and were conquered themselves, but our findings are consistent with the pattern we have just described in the following sense: Big-God religions provide greater wealth and induce better state capacity to the rulers who adopt them; this wealth attracts continual probing and occasional conquest by less wealthy, less politically organized fringe rulers without Big Gods; the new rulers themselves find Big Gods more profitable to adopt and the cycle starts anew with new probings from the fringes of "civilization." This cyclical historical pattern has been long identified by the 14th century Arab historian and social scientist Ibn Khaldûn (see Khaldûn 1994) who had emphasized the gradual "softening" that occurs in sedentary civilizations that makes them ripe for conquest by hardened mountaineers and nomads. Our approach of course does not preclude that but focuses on the advantage conferred by greater ruler legitimacy and large-society morality brought about by Big Gods. Given the historical record, it is not individual state survival that a Big God facilitates but, through its advantage, a Big God lengthens its own chance of survival by inducing successive heathen conquerors to convert as well as keeping the unconquered in its camp.

\section{Anarchy with morality}

The defining characteristic of any state is the provision of security: personal, physical, or property security. Economic activity presupposes basic security and other public goods cannot be provided safely without security. To clarify ideas and serve as a basis of comparison with the subsequent modeling of states under for-profit rulers, we begin with anarchy, a setting in which security is the main concern and the population sorts itself between producers and bandits. To the analogous framework of Konrad and Skaperdas (2012), in which individuals care solely about material payoffs, we add psychological payoffs that believers have depending on whether they become producers or bandits. For simplicity, non-believers (or heathens) only care about material payoffs. Morality is the sole determinant of psychological payoffs here. The psychological payoffs due to legitimacy by necessity require the presence of a state and will thus be introduced in the next section.

Each producer has one unit of a resource that he can distribute between work and self-protection - the higher is the level of self-protection, the lower is the amount of work and the lower is the output that can be produced. Denoting this self-protection activity by $x$, a producer can keep a share $s(x)$ of output away from bandits, where $s(x)$ is increasing, differentiable, and strictly concave in $x$, with $s(x) \in[0,1], s(0)=0$ and $s(1)=1$. 
Believers who become producers have the additional psychological payoff $\mu_{p}>0$, so that their total payoff becomes:

$$
U_{\mu p}(x)=s(x)(1-x)+\mu_{p}
$$

Heathens who become producers correspondingly only have the material payoff:

$$
U_{h p}(x)=s(x)(1-x)
$$

We do not assume that heathens do not have moral psychological payoffs, but that they are different from Big-God beliefs in the sense that they are better suited for small-scale rather than large-scale societies (as argued in Henrich et al. 2001, or Norenzayan 2013). The notions of stealing and banditry, for example, tend to be looked down upon more in Big-God religions than in pagan and tribal religions. We thus effectively normalize the moral payoff of heathens to zero.

Each producer chooses a level of self-protection $x$ so as to maximize their payoff. Let $x^{*}$ denote the unique level of optimal self-protection, which is independent of the psychological payoff $\mu_{p}$ (and thus both believer and heathen producers choose the same level of self-protection).

Bandits are looking for producers to prey upon. Let $p$ denote the number of producers and let $b$ represent the number of bandits so that $p+b=1$. All bandits have the same material payoff $\left[1-s\left(x^{*}\right)\right]\left(1-x^{*}\right) \frac{p}{b}=\left[1-s\left(x^{*}\right)\right]\left(1-x^{*}\right) \frac{p}{1-p}$. That is, bandits extract $1-s\left(x^{*}\right)$ of output from each producer who has not been previously robbed and the more peasants there are relative to bandits, the better it is for a bandit. Then, letting $s^{*} \equiv s\left(x^{*}\right)$, the payoffs of believer and heathen bandits are:

$$
\begin{array}{rlrl}
U_{\mu b}(p) & = & \left(1-s^{*}\right)\left(1-x^{*}\right) \frac{p}{1-p}-\mu_{b} \text { where } \mu_{b}>0 \\
U_{h b}(p)= & \left(1-s^{*}\right)\left(1-x^{*}\right) \frac{p}{1-p}
\end{array}
$$

That is, a believer who becomes a bandit has a positive psychological cost $\mu_{b}$. Let $U_{\mu p} \equiv s^{*}(1-$ $\left.x^{*}\right)+\mu_{p}$ and $U_{h p} \equiv s^{*}\left(1-x^{*}\right) \cdot-$

We are interested in determining the shares of the population who become producers and bandits as a function of their identities and other parameters. In particular, we define an anarchic equilibrium to be a number of peasants $p^{*}$ (and a number of bandits $b^{*}$ where $b^{*}=1-p^{*}$ ) such that no producer wants to become a bandit $\left(U_{i p} \geq U_{i b}\left(p^{*}\right)\right.$ for $\left.i=\mu, h\right)$ and no bandit wants to become a producer $\left(U_{i b}\left(p^{*}\right) \geq U_{i p}\right.$ for $\left.i=\mu, h\right)$. The equalities in payoffs hold when there are both producers and bandits of an identity; strict inequalities can hold only when those with an identity become solely either producers or bandits.

The number of producers and bandits depends on the relative number of believers and heathens in the population. Let $\beta \in[0,1]$ denote the proportion of the population that are believers. 
Proposition 1 summarizes the anarchic equilibrium for the various values of believers.

Proposition 1: There is a unique anarchic equilibrium for every fraction of believers $\beta \in$ $[0,1]$. In particular:

(i) When $\beta \in\left[0, s^{*}\right)$, the equilibrium number of producers equals the share kept by each producer $\left(p^{*}=s^{*}\right)$. All the believers become producers, $s^{*}-\beta$ of heathens become producers and the remainder $\left(1-s^{*}\right)$ become bandits.

(ii) When $\beta \in\left[s^{*}, \frac{s^{*}\left(1-x^{*}\right)+\mu}{\left(1-x^{*}\right)+\mu}\right]$ (where $\left.\mu \equiv \mu_{p}+\mu_{b}\right)$, producers comprise of all believers $\left(p^{*}=\beta\right)$ and all heathens become bandits.

(iii) When $\beta \in\left(\frac{s^{*}\left(1-x^{*}\right)+\mu}{\left(1-x^{*}\right)+\mu}, 1\right], p^{*}=\frac{s^{*}\left(1-x^{*}\right)+\mu}{\left(1-x^{*}\right)+\mu}$, all heathens become bandits. All producers are believers but $\beta-\frac{s^{*}\left(1-x^{*}\right)+\mu}{\left(1-x^{*}\right)+\mu}$ believers become bandits.

(For all proofs not included in the main text, please see the Appendix.)

Figure 1 about here

Figure 1 shows how the number of producers varies with the number of believers in a stepwise fashion. It is drawn assuming $s(x)=x$ and $\mu=0.25$. Total output, being proportional to the number of producers $\left(p^{*}\left(1-x^{*}\right)\right)$, follows exactly the same trajectory. At a proportion of believers below the share of output that producers keep away from bandits (i.e., $s^{*}$ ), producers do not increase as the number of believers increase - over that range, any extra believers become producers and the displaced heathen producers are replaced by heathen bandits, not changing the essential nature of the anarchic equilibrium in the complete absence of believers.

The effect of believers on the economy becomes substantial after they reach the critical mass of $s^{*}$. As the proportion of believers increases beyond that level all extra believers become producers and displace heathens who are bandits. The remaining heathens are all bandits whose payoff nevertheless increases as the number of believer producers increases.

This process of strictly increasing producers in the number of believers is arrested when believers reach such a level - and heathens are reduced sufficiently - so as to tempt some believers to become bandits. That threshold level $\left(\frac{s^{*}\left(1-x^{*}\right)+\mu}{\left(1-x^{*}\right)+\mu}\right)$ depends positively on the sum $(\mu)$ of the psychological benefit of a believer-producer and the psychological cost of a believer-bandit as well as on the self-protection share of producers $s^{*}$. Even when everybody is a believer, the number of producers remains at that level - despite the psychological cost, the material benefits of banditry are compelling given that there are too many producers to prey upon.

Thus far, all security is individually provided. Morality can help increase production and reduce banditry but even when everybody is a believer it cannot completely eliminate banditry. A possibly complementary alternative to morality is greater levels of security that could be provided by the community more efficiently than could be provided individually; building houses close to one 
another to effectively have a fort, having a militia, developing a legal and justice system. Ideally such collective security could be provided by a self-governing community. However, a "Leviathan", a for-profit ruler could also provide such security. The problem is that for-profit rulers could use the means of violence at their disposal not just against bandits but also against the producers themselves and extract from them even more than bandits ever could. Konrad and Skaperdas (2012), in models with material payoffs only, show that self-governing communities are best in terms of material welfare. However, they are at a severe disadvantage in the presence of for-profit rulers when they have to fight against them to maintain their independence. Self-governing communities have to be small to control free-rider problems but they face formidable problems in controlling both internal and external security, the latter against for-profit rulers. This is consistent with the dearth of self-governing communities in history. ${ }^{8}$ Moreover, Big-God religions were typically first adopted by rulers and their narrow elites surrounding them. Therefore, in the remainder we will examine models with for-profit rulers (who can also be believers) providing collective security.

\section{Big-God ruler: preliminaries}

In addition to producers taking self-protection measures, we now introduce a single ruler who can provide security as a public good by hiring guards and having other means at his disposal to protect producers against bandits. Let $g$ denote the number of guards, the input to the public good that provides security. The output of that good is $\gamma g \in[0,1]$ (where $\gamma>1$ ). While $g$ is treated as exogenous, $\gamma$, which influences the effectiveness of protection offered by guards, is interpreted as a measure of state capacity and considered endogenous in the long-run in Section 6. For every level of self-protection by an individual producer and level of $g$ provided by the ruler, each producer keeps the following share of his production away from bandits: $s(x+\gamma g)$ if $x+\gamma g \leq 1 ; 1$ if $x+\gamma g \geq 1$. (Note from the previous section that $s(1)=1$.)

The question then becomes why would a producer ever engage in self-protection, given that selfprotection takes away resources from production (as production equals $1-x$ ). The reason is that the ruler does not just provide collective security through the hiring of guards out of the goodness of his heart, as the Seven Samurai or the Magnificent Seven might do. In addition to providing security against bandits, guards double up as enforcers in extracting tribute from producers. In particular, we assume that producers can keep away the same share of their production from the

\footnotetext{
${ }^{8}$ Konrad and Skaperdas (2012) examine two polar extremes: The case with a ruler who makes all profits and the case of an egalitarian community that provide collective goods voluntarily. Of course, in practice there have been many intermediate governance structures, from fairly egalitarian democracy in some early Mesopotamian and classical Greek city-states to ruling elite self-governance in Medieval Europe (for the latter see, e.g., Salter and Young 2018). Myerson (2008) shows how powerful rulers might want restraint on their power to maximize their profits. Skaperdas (2014) discusses conditions under which self-governance might emerge. In what comes next, we do not conceive of the state's profits to literally go to a single person but a ruling elite, which is perhaps narrow, that shares these profits.
} 
ruler and his guards as they can keep away from bandits. We could expect at least some rulers to be able to extract more out of producers than bandits can but our qualitative results do not change without complicating the analysis unnecessarily. ${ }^{9}$ Then, the tax rate, $\tau$, received by the ruler is the difference between what is kept away from bandits and what producers can keep away from guards:

$$
\tau=s(x+\gamma g)-s(x)
$$

By increasing the number of guards the ruler automatically increases the tax rate, provided of course that $x+\gamma g \leq 1$.

Given than a ruler can extract the same amount as a bandit, a heathen producer's optimization problem is exactly the same as before and their choice of self-protection is the same as under anarchy, $x^{*}$, so that their production is also the same as under anarchy, $1-x^{*}$.

It is different, however, for a producer who is a believer. In particular, the ruler's status or prestige - and the personal contribution to that of the producer - provides the producer with a psychological payoff. ${ }^{10}$ This is also in accordance with "giving Caesar what belongs to Caesar." We therefore modify a believer's payoff so that he or she partly values the tax paid to the ruler:

$$
U_{\mu p}=s(x)(1-x)+\mu_{p}+\sigma \tau(1-x) \text { where } \sigma \in(0,1)
$$

Given that the tax rate partly depends on self-protection through (5), the payoff function of a believer producer becomes

$$
U_{\mu p}(x)=[(1-\sigma) s(x)+\sigma s(x+\gamma g)](1-x)+\mu_{p}
$$

The optimal level of self-protection for a producer who is a believer and ascribes status to the ruler turns out to be lower than that under anarchy or that of a heathen producer.

Proposition 2: Let $\sigma \in(0,1)$ and let $x^{\sigma}$ denote the optimal level of self protection of a producer who is a believer with the payoff function in (6). Then,

(i) $x^{\sigma}<x^{*}$ and $x^{\sigma}$ is decreasing in $\sigma$;

(ii) production of a believer producer $\left(1-x^{\sigma}\right)$ is higher than that of a heathen producer $\left(1-x^{*}\right)$ and is increasing in $\sigma$;

(iii) the material payoff of a producer who is a believer is decreasing in $\sigma$ and is lower than that of a heathen producer.

By putting fewer resources into self-protection, believer producers devote more resources to

\footnotetext{
${ }^{9}$ Konrad and Skaperdas (2012) examine that case in the absence of believers in Big-God religion. Since rulers can extract more from producers than bandits can, self-protection is higher and production lower than in anarchy. Rulers extract a higher share of production than bandits could, and overall welfare is also lower than under anarchy.

${ }^{10}$ For introducing such status payoffs in models, see Shayo (2009), Sambanis and Shayo (2013), and Sambanis et al. (2015). For a rational-choice approach to religious authority, see McBride (2016). Konrad and Qari (2012) provide evidence of greater tax compliance for those who feel more patriotic.
} 
production and allow a greater share to the ruler and bandits. That can be of advantage to the ruler. However, another advantage to the ruler is that he could potentially hire believers as guards at a lower cost than heathens because of part (iii) of the Proposition: believer producers earn materially less than heathen producers because they value what they give to the ruler. An example of the self-protection technology is class of functions $s(x)=x^{\alpha}$ for $\alpha \in(0,1]$. In fact, to facilitate analytical results and for simplicity we will assume for the remainder of the paper this particular functional form with $\alpha=1$.

Assumption A: $s(x)=x$

Under Assumption A, we have the following values for different variables of interest:

$$
\begin{aligned}
& x^{*}= \\
& 1 / 2,1-x^{*}=1 / 2, U_{h p}=s^{*}\left(1-x^{*}\right)=1 / 4 \\
& x^{\sigma}= \frac{1-\sigma \gamma g}{2},\left(1-x^{\sigma}\right)=\frac{1+\sigma \gamma g}{2}, x^{\sigma}\left(1-x^{\sigma}\right)=\frac{1-(\sigma \gamma g)^{2}}{4}
\end{aligned}
$$

The tax rate on both heathen and believer producers under Assumption A turns out to be the same and equals $\gamma g$. We consider $g$ to be given parametrically, perhaps keeping in mind the short- and medium run, but our results in the remainder hold for any values of $g$ that satisfy the other assumptions of the model. We think of $\gamma$ as the level state capacity, the ability of the ruler and the elites that surround him to organize the guards for protection against bandits but also in extracting taxes from producers. Since the maximum of security provided by the combined inputs of the individual and the ruler cannot exceed 1, i.e., $x^{*}+\gamma g \leq 1$ and, by Assumption $\mathrm{A}, x^{*}=\frac{1}{2}$, we must have $\gamma g \leq \frac{1}{2}$. In fact, for the remainder of this paper, we examine the cases in which $\gamma g<\frac{1}{2}$ or that there is imperfect security and there are some bandits (heathens or believers), for otherwise there would be no reason to have morality among believers that makes it costly for them to become bandits.

\section{A ruler with believer subjects}

We now turn to examining the ruler's profit as a function of the fraction of believers $\beta \in[0,1]$ under his rule, with the remainder of the subjects $(1-\beta)$ as heathens. The timing is as follows:

1. The ruler decides how many of the $g$ guards will be believers and how many heathens.

2. The remaining population $(1-g)$ makes choices between becoming producers and bandits so that no producer has an incentive to become a bandit and no bandit has an incentive to become a producer. 
Recall that the number of guards determines under Assumption A both the level of the public good $\gamma g$ that is partly protecting producers from bandits as well as the tax rate, also $\gamma g$. The payoff of a heathen producer will be the same as under anarchy, which under Assumption $\mathrm{A}$ is $x^{*}\left(1-x^{*}\right)=\left(\frac{1}{2}\right)\left(\frac{1}{2}\right)=\frac{1}{4}$, whereas the payoff of a heathen bandit should be at least equal to that of a heathen producer; it would be strictly higher if there are no heathen producers. ${ }^{11}$ Heathens hired as guards by the ruler will have to receive the going payoff for heathens which will be that of the producer (i.e., $\frac{1}{4}$ ). Also under Assumption A, the payoff of a believer producer is

$$
\begin{aligned}
U_{\mu p}=\quad & \frac{1-(\sigma \gamma g)^{2}}{4}+\mu_{p}+\sigma \gamma g \frac{1+\sigma \gamma g}{2} \\
= & \frac{(1+\sigma \gamma g)^{2}}{4}+\mu_{p}
\end{aligned}
$$

where the material part of the payoff is from (7). The payoff of a believer bandit will be at least as great as that of believer producer and there will be no believer bandits unless there are some believer producers. Moreover, because believer bandits have to pay a moral cost $\left(\mu_{b}\right)$ and the alternative payoff of being a producer in (8) includes both a moral payoff and the status payoff, there will be no believer bandits unless there are some heathen bandits (except for the limiting case when there are no heathens and $\beta=1$ ). Believers hired as guards by the ruler enjoy the psychological payoffs of $\mu_{p}+\sigma \gamma g \frac{1+\sigma \gamma g}{2}$ that believer producers have (in (8)) and therefore they only need to be paid $\frac{1-(\sigma \gamma g)^{2}}{4}$ in material payoff by the ruler (which is less than $\frac{1}{4}$, the payoff of heathen guards). ${ }^{12}$ Thus, from the point of view of the ruler, believer guards are cheaper than heathen guards.

For given $\beta$, the number of guards and the types of guards chosen by the ruler determine how believers and heathens sort themselves between producers and bandits. The ruler's profits are as follows:

$$
\pi_{r}=\nu_{\mu}(g) \gamma g \frac{1+\sigma \gamma g}{2}+\nu_{h}(g) \gamma g \frac{1}{2}-g_{\mu} \frac{1-(\sigma \gamma g)^{2}}{4}-g_{h} \frac{1}{4}
$$

where $g=g_{\mu}+g_{h}, \nu_{\mu}(g)$ is the induced number of believer producers, $\nu_{h}(g)$ is the induced number of heathen producers, $g_{\mu}$ are the believer guards hired and $g_{h}$ are the heathen guards hired. The first term includes the tax on each believer producer $(\gamma g)$ and the output of a believer producer $\left(\frac{1+\sigma \gamma g}{2}\right)$ and similarly for the second term for heathen producers.

The types of outcomes in terms of who is hired as guard and who becomes producer or bandit

\footnotetext{
${ }^{11}$ It is not possible to have the payoff of a heathen producer strictly higher than that of a heather bandit as it is fixed by the amount of their production and self-protection effort.

${ }^{12}$ It is also possible for guards to have higher psychological payoffs than producers as the ruler can motivate them with team and religious instruction that are normally higher than peasant producers. They could thus offer even lower material wages than those expected by believer producers. Of course, such a specification would make our results stronger than they are.
} 
depends on the number of believers relative to the number of heathens. Table 1 summarizes the four intervals of $[0,1]$ as the number of believers becomes successively higher. (The values of $\beta_{0}$ and $\beta_{1}$ depend on the other parameters of the model and will be derived in due course.)

Table 1 about here

For illustration about how we proceed in showing these types of outcomes, we begin with the first case whereby $\beta \in[0, g]$. Typically, in this case there are fewer believers than guards to hire (except when $\beta=g$ ) and therefore the ruler has the option of hiring all believers as guards with the rest of the guards to be hired will necessarily will have to be heathens. Believers are cheaper to hire than heathens but they also provide greater tax revenue as producers than heathens $\left(\gamma g \frac{1+\sigma \gamma g}{2}\right.$ vs. $\left.\gamma g \frac{1}{2}\right)$. However, the decision by the ruler whether to hire believers as guards or to let them choose to become producers is not a straight calculation between the extra tax revenue from a believer producer versus the cost savings from hiring the same believer as guard. The reason is that a believer producer is also more lucrative to bandits as bandits get both a bigger share $\left(\frac{1+\sigma \gamma g}{2}-\gamma g\right.$ vs $\left.\frac{1}{2}-\gamma g\right)$ and a bigger target output $\left(\frac{1+\sigma \gamma g}{2}\right.$ vs $\left.\frac{1}{2}\right)$ from a believer producer than from a heathen producer. That is, there is a significant "leakage" to bandits if the ruler were to have a believer become a producer, especially in the presence of heathen bandits, instead of hiring him as a guard.

It turns out that it is optimal for the ruler to hire all believers as guards when $\beta \in[0, g]$. (We show in the Appendix why having them turn into producers is not optimal for the ruler.) Given that all $\beta$ of the believers become guards and the rest of the guards are heathens, how do the remaining heathens distribute themselves between producers and guards? With the number of producers denoted by $p\left(=\nu_{h}(g)\right)$ and that of bandits by $1-p-g$, the payoff of heathen producer $\left(\frac{1}{4}\right)$ must be equal to that of bandits:

$$
\frac{1}{4}=\left(\frac{1}{2}-\gamma g\right) \frac{1}{2} \frac{p}{1-p-g}
$$

which yields

$$
p=\frac{1-g}{2(1-\gamma g)}
$$

The ruler's payoff (see (9)) then becomes:

$$
\begin{aligned}
\pi_{r}(\beta \in[0, g])=\frac{1-g}{2(1-\gamma g)} \gamma g \frac{1}{2}-\beta \frac{1-(\sigma \gamma g)^{2}}{4}-(g-\beta) \frac{1}{4} & \\
& =\frac{g}{4} \frac{(\gamma-1)}{(1-\gamma g)}+\frac{\beta}{4}(\sigma \gamma g)^{2}
\end{aligned}
$$


We summarize the main findings about the ruler's payoff as a function of the number of believers in Proposition 3.

Proposition 3: Let Assumption A be satisfied. Then, the population of subjects among the different occupations is distributed as in Table 1 and the following results hold:

(i) For $\beta \in[0, g]$, the ruler's payoff is strictly increasing in $\beta$;

(ii) For $\beta \in\left(g, \beta_{0}\right)$, where $\beta_{0}=\frac{1+g(1+\sigma \gamma g-2 \gamma g)(1+\sigma \gamma g)}{1+(1+\sigma \gamma g-2 \gamma g)(1+\sigma \gamma g)}$, the ruler's payoff is strictly decreasing in $\beta$;

(iii) For $\beta \in\left[\beta_{0}, \beta_{1}\right]$, where $\beta_{1}=\frac{(1+g)(1+\sigma \gamma g)^{2}+4 \mu-2 \gamma g^{2}(1+\sigma \gamma g)}{2(1+\sigma \gamma g)^{2}+4 \mu-2 \gamma g(1+\sigma \gamma g)}$, the ruler's payoff is strictly increasing in $\beta$;

(iv) For $\beta \in\left(\beta_{1}, 1\right]$, the ruler's payoff is constant at its level at $\beta_{1}$.

Figure 2 about here

Figure 2 shows how a Big-God ruler's profit varies with the share of believers under his rule. It satisfies Assumption A and is drawn for parameter values $g=0.16, \gamma=3, \sigma=0.8$, and $\mu=0.25$. The ruler's profit is higher than a heathen's one (assumed to be the one where $\beta=0$ ) at low enough and high enough levels of $\beta$. For intermediate levels of $\beta$, a Big-God ruler can have a slightly lower profit than a heathen one; those are the levels at which there is too much "leakage" to bandits from believer producers. ${ }^{13}$ At low levels of believers (below $g$ ) the ruler solely benefits by having to spend less on guards because believer guards require lower material compensation since they also derive moral and status payoffs. It would not benefit the ruler to have believers become producers as they would present a more lucrative target to bandits than heathen producers are. In intermediate ranges of $\beta\left(\in\left(g, \beta_{0}\right)\right)$, the addition of believer producers induces more heathens to become bandits to the extent that they reduce both the total number of producers and the ruler's payoff. Only when there are enough believers so that heathens become bandits exclusively $\left(\beta \geq \beta_{0}\right)$, new believers increase the ruler's payoff one-for-one by the amount of tax collected. When there are plentiful enough believers (beyond $\beta=\beta_{1}$ ) so as to present lucrative enough targets even for believers, do the extra believers become bandits. Then, over that range, any heathen bandit is replaced by a believer who also becomes a bandit. That critical level $\beta_{1}$ can increase, so that more believers become producers, when the moral payoffs of believers $\left(\mu=\mu_{p}+\mu_{b}\right)$ increase.

Mature Big-God rulers do have a high proportion of believers, and have actively campaigned for their expansion. There have also been dynamic Big-God rulers who initially had a limited number of believers, such as in early Islam, in which the believers were limited to specialists in violence, as it is in the model.

\footnotetext{
${ }^{13}$ That could, of course, be potentially reduced or eliminated if the Big-God ruler were to provide greater protection to believer producers than heathen producers but that might seem arbitrary from a modeling and substantive viewpoint.
} 
It should be emphasized that essentially all the material benefits from the publicly provided security (through $\gamma g$ ) are captured by the ruler as profits. Heathens have the same payoffs as under anarchy, except when there are few enough heathens who co-exist with believer producers (that is, for $\left.\beta>\beta_{0}\right) .{ }^{14}$ In fact, believers receive a lower material payoff than under anarchy as they are compensated by the psychological status payoff from valuing the ruler's revenue.

Note that morality does not play a role in increasing the ruler's profits except in increasing the level of $\beta_{1}$ and, therefore, having profits increase as $\beta$ increases when $\beta \leq \beta_{1}$. Furthermore, all extra economic benefits in the model come from the increased security and the fewer resources devoted to self-protection by believer producers. There is no trade that could benefit from both the increased economic activity due to higher security and the easier contract enforceability when a greater proportion of the population consists of believers with moral preferences. To accommodate such considerations, we could modify the model in the following manner: Let $A(y, \beta \mu)$ be an increasing function of the total output in the economy $(y)$ and of the average morality in the economy $(\beta \mu)$. With $A(y, \beta \mu)>1$ for $y>\bar{y}$ for some $\bar{y}$ and $\beta \mu>0$, it can be a coefficient that multiplies all material payoffs (in an analogous manner to the $A$ in the $A k$ model of endogenous growth theory - see Aghion and Howitt 1997). Then, as output increases as a result of having more security and more believer producers (who produce more than heathen producers) as well as having higher average morality that enhances contract enforcement, the effects of an increasing $\beta$ would be higher for the ruler's profits but also for overall output as well.

\section{A believer ruler investing in Big God}

In the 25 years between his victory [over Maxentius] and his death, Constantine ordered a sequence of huge church buildings, from Rome to the Holy Land. All were built largely at the Emperor's expense. This deluge of Christian publicity exceeded any other programme in precious stone which was realized by a ruler in antiquity...

... In Spring 313, Constantine wrote again to the pagan governor of North Africa, exempting the clergy of the recognized Catholic Church from the burdens of civic office.... The Christian prayers, said Constantine, were intimately connected with the safety of the state. Lane Fox (1986, p. 623)

Religious beliefs start organically and usually fulfill local and specialized needs that can grow or fizzle out in competition with other beliefs. In the Roman Empire, Christianity was one of many competing beliefs of both Big-God religions and traditional pagan ones. When Emperor

\footnotetext{
${ }^{14}$ This is partly due to the simplifying assumption that producers - either heathens or believers - can resist the ruler and his guards as easily as they can bandits. Making it harder for producers to resist the ruler can be expected to increase resources by producers expended on self-protection and reduce production. This is not necessarily better for the ruler as it could reduce total tax revenue. See Konrad and Skaperdas (2012) for such modeling without the psychological payoffs we have in this paper.
} 
Constantine converted to Christianity, no more than 5\% of Rome's population has been estimated to have been Christian and the countryside had almost none of them (Lane Fox 1986, Ch.6). Moreover, there was not one version of Christianity even then, as Arianism was a major competitor to what turned out to be the Catholic Orthodox version after the Council of Nicaea in 325, which took place under the watchful eye of the emperor. Christianity became the state religion of the Roman Empire and all European states that came to existence afterwards. Emperors, kings, and the aristocracy built churches, endowed monasteries, sponsored the clergy and gave them privileges, punished pagans and heretics, and tried to evangelize the heathen countryside.

All this took significant economic resources but both spreading and maintaining the salience of Big God in people's everyday lives requires continual reminders (Norenzayan 2013). We can think of these expenditures as investments on the part of rulers. In terms of our model, the investments can be both at the extensive margin (by increasing the share of believers $\beta$ ) and at two intensive margins, by increasing the status parameter $\sigma$ or the morality parameter $\mu$. Evangelizing missionaries are mostly operating at the extensive margin; having a village church and priest, regular mass and Sunday school operate at the intensive margins.

There is one problem, however, about the model of a ruler who solely cares about material profits for, as we have seen, over the range of fraction of believers $\beta$ in $\left(g, \beta_{0}\right)$ increasing that fraction reduces profits. Such a ruler would not have an incentive to invest in religion, unless his investment could leapfrog the number of believers considerably beyond $\beta_{0}$, and that would be difficult to achieve within one ruler's reign. On the contrary, there would be an incentive to disinvest in Big-God religion.

Qualitative historical evidence indicates that many rulers who do invest in religion are believers themselves (or, if they are not believers, they are able to fake their non-belief very well). It would be difficult to rationalize Constantine's choice to publicly embrace and support Christianity without any resort to genuine belief. For, at the time, the Roman elites and the army were overwhelmingly pagan and coming out in support of Christianity was controversial to say the least (see the accounts of Lane Fox 1986, or Fletcher 1997). ${ }^{15}$ There are also many examples of later kings in Europe who converted to Christianity for opportunistic reasons and did not do anything to advance the religion (examples include Anglo-Saxon kings in England in the sixth century, Saxon kings in Germany in the seventh century, of Wend (Slavic) rulers in what is now East Germany in the ninth and tenth centuries - see Fletcher 1997). Only after European rulers did become plausibly believers did they invest in spreading Christianity. As an example away from Europe, we can consider King Ashoka of the Mauryan empire in Northern India (fourth century BCE) who in mid-reign changed his previous ruthless ways and became a believer in, and apostle of, Buddhism (Keay 2000).

To the material profit of the previous section we thus add the following psychological payoff

\footnotetext{
${ }^{15}$ Furthermore, building a church that might take more than one's lifetime (as it has routinely occurred) requires an especially long-term horizon and therefore an extended notion of profitability to include a dynasty, while it is consistent with genuine belief on the part of the ruler who undertakes such a project.
} 
for a ruler who is a believer: $\theta \beta h(\sigma, \mu)$ where $\theta$ is a positive parameter that represents the relative strength of the psychological payoff to material profit and $h(\sigma, \mu)$ is function that is increasing in both of its arguments. An example of $h(\sigma, \mu)$ is just the payoff of a believer producer: $h(\sigma, \mu)=$ $\frac{(1+\sigma \gamma g)^{2}}{4}+\mu_{p}$ (where we can set $\mu_{p}=\mu-m$ for some constant $m=\mu_{b}>0$ ), and for specificity we shall employ this particular form. Then, the total payoff for a believer ruler for $\beta \in\left(g, \beta_{0}\right)$ becomes (see proof of part (ii) of Proposition 3 for the profit component):

$$
\pi_{r \mu}\left(\beta \in\left(g, \beta_{0}\right)\right)=\frac{g}{4} \frac{\left(\gamma-1+(\sigma \gamma g)^{2}\right)}{(1-\gamma g)}+\beta\left[\theta\left(\frac{(1+\sigma \gamma g)^{2}}{4}+\mu-m\right)-\frac{\sigma^{2}(\gamma g)^{3}}{4(1-\gamma g)}\right]
$$

For this payoff to be increasing in the fraction of believers $\beta \in\left(g, \beta_{0}\right)$, the following Assumption needs to be satisfied:

Assumption B: $\theta>\frac{\sigma^{2}(\gamma g)^{3}}{(1-\gamma g)\left[(1+\sigma \gamma g)^{2}+4 \mu-4 m\right]}$

An example of the total payoff of a ruler who is a believer and satisfies Assumption B, so that payoff is increasing everywhere in $\beta$, is depicted in Figure 3 which satisfies assumptions A and B and uses the same parameter values as Figure 2 with the addition of $m=0.05$ and $\theta=0.07$.

Figure 3

Denoting by $I_{\beta}, I_{\sigma}$, and $I_{\mu}$ the investments in $\beta, \sigma$, and $\mu$, let $c\left(I_{\beta}, I_{\sigma}, I_{\mu}\right)$ be the joint cost function. To ensure interior solutions, we assume a strictly convex cost function and, to allow for positive investments when there are positive marginal benefits to an investment, we can assume $\frac{\partial c}{\partial I_{i}} I_{i} \rightarrow 0=0$ for $i=\beta, \sigma, \mu$. Furthermore, we assume there are increasing and concave functions of each investment so that $\beta=\beta\left(I_{\beta}\right), \sigma=\sigma\left(I_{\sigma}\right)$, and $\mu=\mu\left(I_{\mu}\right)$. In addition to investments in Big God, we consider the possibility of investing in state capacity so that $\gamma=\gamma(S)$ (where $\gamma(\cdot)$ is increasing and strictly concave) and $S$ are the corresponding investment expenditures.

Given that the ruler's payoff function has four different segments, the incentives for investments differ across these segments. Nevertheless, qualitatively the incentives have some common features. Consider first the case of $\beta \in[0, g]$ in which the profit of the ruler is as in (10) with the addition of the psychological component $\theta \beta h(\sigma, \mu)$ :

$$
\pi_{r \mu}(\beta \in[0, g])=\frac{g}{4} \frac{(\gamma-1)}{(1-\gamma g)}+\frac{\beta}{4}(\sigma \gamma g)^{2}+\theta \beta\left[\frac{(1+\sigma \gamma g)^{2}}{4}+\mu-m\right]-c\left(I_{\beta}, I_{\sigma}, I_{\mu}\right)-S
$$

Letting superscript " $g$ " denote optimal investment values in this segment, the first-order conditions 
for investments in $\beta, \sigma, \mu$, and $S$ are as follows

$$
\begin{array}{cc}
\frac{\beta^{\prime}\left(I_{\beta}^{g}\right)}{4}\left[(\sigma \gamma g)^{2}+\theta\left((1+\sigma \gamma g)^{2}+4(\mu-m)\right]=\right. & \frac{\partial c\left(I_{\beta}^{g}, I_{\sigma}^{g}, I_{\mu}^{g}\right)}{\partial I_{\beta}} \\
\frac{g \beta \gamma}{2} \sigma^{\prime}\left(I_{\sigma}^{g}\right)[\theta(1+\sigma \gamma g)+\sigma \gamma g]=\frac{\partial c\left(I_{\beta}^{g}, I_{\sigma}^{g}, I_{\mu}^{g}\right)}{\partial I_{\sigma}} & \mu^{\prime}\left(I_{\mu}^{g}\right) \theta \beta= \\
\frac{g}{4} \gamma^{\prime}\left(S^{g}\right)\left[\frac{1-g}{(1-g \gamma)^{2}}+2 \beta \sigma(\theta(1+\sigma \gamma g)+\sigma \gamma g)\right]=1 &
\end{array}
$$

The left-hand-side of each condition represents the marginal benefit of investing in the particular attribute, with the right-hand-side representing marginal cost. Note that the sole marginal benefit of investing in morality, in the third equation, comes from the believer ruler's own psychological payoff. In the absence of that psychological payoff, there is no incentive to invest in morality in this and any other case except possibly $\beta \in\left(\beta_{1}, 1\right]$.

Note that in the first condition (investment in the fraction of believers), the marginal return on investing in $\beta$ is increasing in $\sigma, \gamma$, and $\mu$. This implies that if these other variables were to increase, there would be an incentive to increase the investment in $\beta$ as well. Inspection of the second condition reveals that higher values of $\gamma$ and $\beta$ also increase the marginal return on investing in $\sigma$. The fourth condition also shows how higher values of $\sigma$ and $\beta$ increase the marginal return on investing in $\gamma$ as well. That is, investments in $\beta, \gamma$, and $\sigma$ are complementary to one another.

Investments in morality are not fully complementary to the other investments for this case. We can use the same procedure to study the incentives for a ruler (who is a believer) to invest in $\beta$, $\sigma, \gamma$ and $\mu$ for the remaining three segments of $\beta$ as well. The same findings for complementarity hold for the segment $\left[\beta_{0}, \beta_{1}\right]$, but less general ones hold for the two other segments. Further, the marginal benefit of investing in morality $(\mu)$ is highest in the segment $\beta \in\left(\beta_{1}, 1\right]$. It is however always increasing in $\beta$ in all segments. We summarize the main results of this section in Proposition 4 .

Proposition 4: Suppose assumptions $A$ and $B$ are satisfied. Then, the following results hold:

(i) A believer ruler's total payoff is everywhere increasing in $\beta$.

(ii) For $\beta \in[0, g]$ investments in the number of believers $(\beta)$, in the legitimacy of the ruler $(\sigma)$, and in state capacity $(\gamma)$ are complementary.

(iii) For $\beta \in\left(g, \beta_{0}\right)$ the marginal return on investment in the number of believers $(\beta)$ is increasing in the legitimacy of the ruler $(\sigma)$ and in state capacity $(\gamma)$ for sufficiently high $\theta$.

(iv) For $\beta \in\left[\beta_{0}, \beta_{1}\right]$ investments in the number of believers $(\beta)$, in the legitimacy of the ruler $(\sigma)$, and in state capacity $(\gamma)$ are complementary.

(v) For $\beta \in\left(\beta_{1}, 1\right]$, investments in believers' morality $(\mu)$ have the highest marginal benefit than 
any other range of $\beta$.

(vi) The marginal return on investment in morality $(\mu)$ is increasing in the number of believers ( $\beta$ ) and investment in $\beta$ stimulates investment in $\mu$.

The complementarities among the different types of investments concern the marginal benefit sides of the investments. It is also highly plausible to have complementarities on the cost side, especially among the three types of investments in religion and that is the reason we have specified it as a joint cost function $c\left(I_{\beta}, I_{\sigma}, I_{\mu}\right)$. What this specification allows is, for example, the catechism and instruction by religious figures on morality to complement messages on the piety of the monarch and his divine right to be a monarch. Houses of religious worship can also play all three roles in increasing recruitment and conversion, in deepening morality among worshippers, and in enhancing the sense of the ruler's legitimacy.

The fact that the ruler's profits as well as the ruler's total payoff (including the psychological one) are maximal at very high levels of believers and the incentives for various investments are strong at high levels all imply a drive towards consolidation and institutionalization of Big-God religions so that they become essentially monopoly state religions. Church or mosque or temple becomes a center of community life and believers tightly embedded within them, with the rulers and

Big Gods overseeing all. Some Christian rulers prohibited other religions while some Muslim rulers allowed as their subjects only peoples of the book. To this day, atheists and even agnostics appear to be distrusted the most in almost all countries (Norenzayan 2013, Ch.4). It is not necessary for many polities that all subjects adhered to one particular Big-God religion but it appears to be necessary that subjects must have adhered to some Big-God religion.

Furthermore, the complementarities among state capacity and the different religious investments indicate that the legitimacy and morality functions of Big-God religions along with state capacity can be thought of as a cultural and political "package" which provided an evolutionary advantage to a ruler that would probably not exist by picking and choosing only a subset of such a package. This is analogous to the arguments that Boyd (2017) has made about human evolution - compared to those of other animals - as based on cultures conceived as packages of beliefs, norms, and practices.

\section{Concluding remarks}

We would like to emphasize the last point about Big-God religions providing a package of attributes that enhanced a ruler's evolutionary advantage. This package may have included additional attributes to those we have examined that could be explored in future theoretical or empirical research.

One attribute that Big-God religions might have induced is the consolidation of the aristocracy's identity beyond the tribe, clan or ethnic group. In turn, this more well-defined identity would have reduced free-rider problems and enhanced cohesion of aristocracies, especially in large multi-ethnic states. Another possibly helpful attribute of Big-God religions is that, through their emphasis of 
holy texts or other books, there was a concomitant tendency for higher levels of literacy among state officials that could improve the administrative and legal capacity of the state. For example, the newly converted Anglo-Saxon kings of England codified folk customs into the king's law (Fletcher 1997, p.118). Finally, ruler legitimacy could well go beyond the specific effects of higher tax compliance and lower cost of hiring believers that we have examined here.

As for long-term implications, one side-effect of the adoption of Big Gods was higher levels of economic activity. This is consistent with the intuition in Olson (1993) that a ruler who behaves as a stationary bandit perhaps unintentionally improves the economy. Morality and norms help directly with economic exchange and the ruler's legitimacy improves tax collection and production. That appears to be the case for pre-modern states and their economies, but how much can we extend these effects of Big Gods to modern states and economies? Much of modern economic activity takes place in markets with anonymous buyers and sellers and exchange is often impersonal, requiring formal property rights. Morality and norms are not sufficient for impersonal exchange and constitutionally unconstrained rulers have difficulty commiting to property rights (North et al. 2009). Moreover, the modern nation-state's legitimacy is not based on Divine Will but popular sovereignty and the idea of citizenship. Likewise, national identification is the primary identification of citizens, not religious identification (although national identification is sometimes based on religious identification). Morality and norms are still relevant, however, and the effects of long-ago established states within a modern state's boundaries has been argued (Wimmer 2018) to be an important factor in successful modern economic development. How the legacy of older Big-God states affects modern growth is unclear and worthy of investigation. 


\section{Appendix}

Proof of Proposition 1: Part (i): Let $\beta \in\left[0, s^{*}\right)$ and suppose, as stated in the proposition, all believers become producers and heathens distribute themselves between producers and bandits. The latter would imply that the payoffs of heathens are equalized so that

$$
U_{h b}\left(p^{*}\right)=\left(1-s^{*}\right)\left(1-x^{*}\right) \frac{p^{*}}{1-p^{*}}=s^{*}\left(1-x^{*}\right)=U_{h p}
$$

In such a case, the unique solution for $p^{*}$ is $p^{*}=s^{*}$. Given this equilibrium number of producers, the payoffs of a believer producer and a believer bandit would be related as follows: $U_{\mu p}\left(p^{*}\right)=$ $s^{*}\left(1-x^{*}\right)+\mu_{p}>U_{\mu b}(p *)-\mu_{b}$. Thus, a believer bandit would achieve a payoff strictly lower than that of a producer and therefore a believer could not be a bandit in equilibrium. All believers become producers and since there are $\beta\left(<s^{*}\right)$ of them, the rest of the producers $\left(s^{*}-\beta\right)$ must be heathens. The remainder heathens $\left(1-s^{*}\right)$ must become bandits, with the same payoff as producers. This configuration of proportion of producers (and bandits) and payoffs satisfy the conditions for an anarchic equilibrium.

To show uniqueness, suppose another equilibrium exists with a number of producers $p^{\prime} \neq p^{*}$. Given that $p^{*}=s^{*}$ uniquely solves $U_{h b}\left(p^{*}\right)=U_{h p}$, the other equilibrium must have $U_{h b}\left(p^{\prime}\right) \neq U_{h p}$. There are then two possibilities.

First, we could have $U_{h b}\left(p^{\prime}\right)>U_{h p}$ or that $\left(1-s^{*}\right)\left(1-x^{*}\right) \frac{p^{\prime}}{1-p^{\prime}}>s^{*}\left(1-x^{*}\right) \Longrightarrow p^{\prime}>s^{*}$. Moreover the inequality in heathen payoffs, by the definition of equilibrium, implies than no heathens would become producers - all would become bandits so that $b^{\prime}=1-p^{\prime} \geq 1-\beta$ or that $p^{\prime} \leq \beta$ where $\beta \in\left[0, s^{*}\right)$ and thus $p^{\prime}<s^{*}$, contradicting $p^{\prime}>s^{*}$ in the previous sentence. Therefore, no other equilibrium can exist in this case.

Second, we could have $U_{h b}\left(p^{\prime}\right)<U_{h p}$ or that $\left(1-s^{*}\right)\left(1-x^{*}\right) \frac{p^{\prime}}{1-p^{\prime}}<s^{*}\left(1-x^{*}\right) \Longrightarrow p^{\prime}<s^{*}$. This inequality of heathen payoffs, by the definition of equilibrium, implies that no heathens would become bandits - all would become producers. In addition, the following

$$
\begin{array}{rr}
U_{\mu p} & \equiv \\
& > \\
& s^{*}\left(1-x^{*}\right)+\mu_{p}> \\
& \left(1-s^{*}\right)\left(1-x^{*}\right) \frac{p^{\prime}}{1-p^{\prime}}-\mu_{b}=U_{\mu b}\left(p^{\prime}\right) \text { given that } \mu_{p}>0 \text { oand } \mu_{b}>0
\end{array}
$$

imply $U_{\mu p}>U_{\mu b}\left(p^{\prime}\right)$ or that all believers would also become producers, thus leading to $p^{\prime}=1$, a contradiction to $p^{\prime}<s^{*}<1$. Therefore, no other equilibrium can exist in this case as well and the equilibrium (where $p^{*}=s^{*}$ ) is unique.

Part (ii): Let $\beta \in\left[s^{*}, \frac{s^{*}\left(1-x^{*}\right)+\mu}{\left(1-x^{*}\right)+\mu}\right]$. Then, $p^{*}=\beta$ satisfies $U_{\mu p} \equiv s^{*}\left(1-x^{*}\right)+\mu_{p} \geq(1-$ $\left.s^{*}\right)\left(1-x^{*}\right) \frac{p^{*}}{1-p^{*}}-\mu_{b}=U_{\mu b}\left(p^{*}\right)$ and therefore it is consistent with all believers becoming producers. 
Moreover, $p^{*}=\beta$ implies $U_{h b}\left(p^{*}\right)=\left(1-s^{*}\right)\left(1-x^{*}\right) \frac{p^{*}}{1-p^{*}} \geq s^{*}\left(1-x^{*}\right)=U_{h p}$ and therefore consistent with all heathens becoming bandits so that $b^{*}=1-p^{*}=1-\beta$. Since all equilibrium conditions are satisfied, $p^{*}=\beta$ is an equilibrium.

To show uniqueness, consider another equilibrium with $p^{\prime} \neq \beta$. If $p^{\prime}>\beta$, then at least some producers must be heathens. However, this would require $U_{h b}\left(p^{\prime}\right)=\left(1-s^{*}\right)\left(1-x^{*}\right) \frac{p^{\prime}}{1-p^{\prime}} \leq$ $s^{*}\left(1-x^{*}\right)=U_{h p}$ thereby implying $p^{\prime} \leq s^{*} \leq \beta$ which is a contradiction. Thus we cannot have $p^{\prime}>\beta$.

If $p^{\prime}<\beta$, then at least some believers must be bandits. However, we would then have

$U_{\mu p} \equiv s^{*}\left(1-x^{*}\right)+\mu_{p} \geq\left(1-s^{*}\right)\left(1-x^{*}\right) \frac{\beta}{1-\beta}-\mu_{b}>\left(1-s^{*}\right)\left(1-x^{*}\right) \frac{p^{\prime}}{1-p^{\prime}}-\mu_{b}=U_{\mu b}\left(p^{\prime}\right)$ contradicting the equilibrium condition that believer bandits should be having at least as high a payoff as believer producers.

Therefore no equilibrium other than $p^{*}=\beta$ exists.

Part (iii): Let $\beta \in\left(\frac{s^{*}\left(1-x^{*}\right)+\mu}{\left(1-x^{*}\right)+\mu}, 1\right]$. Having believers become both producers and bandits would equate the payoffs of the two professions so that $U_{\mu p} \equiv s^{*}\left(1-x^{*}\right)+\mu_{p}=\left(1-s^{*}\right)\left(1-x^{*}\right) \frac{p^{*}}{1-p^{*}}-\mu_{b}=$ $U_{\mu b}\left(p^{*}\right)$, which implies $p^{*}=\frac{s^{*}\left(1-x^{*}\right)+\mu}{\left(1-x^{*}\right)+\mu}$. Then, $U_{h b}\left(p^{*}\right)=\left(1-s^{*}\right)\left(1-x^{*}\right) \frac{p^{*}}{1-p^{*}}>\left(1-s^{*}\right)\left(1-x^{*}\right) \frac{p^{*}}{1-p^{*}}-$ $\mu_{b}-\mu_{p}=s^{*}\left(1-x^{*}\right)=U_{h p}$, which implies that no heathens can be producers as required by the equilibrium. Thus, the conditions for the equilibrium described are satisfied.

To show uniqueness, suppose another equilibrium $p^{\prime} \neq \frac{s^{*}\left(1-x^{*}\right)+\mu}{\left(1-x^{*}\right)+\mu}$. If $p^{\prime}>\frac{s^{*}\left(1-x^{*}\right)+\mu}{\left(1-x^{*}\right)+\mu}$, then we would have $U_{\mu b}\left(p^{\prime}\right)=\left(1-s^{*}\right)\left(1-x^{*}\right) \frac{p^{\prime}}{1-p^{\prime}}-\mu_{b}>s^{*}\left(1-x^{*}\right)+\mu_{p}=U_{\mu p}$

as well as

$U_{h b}\left(p^{\prime}\right)=\left(1-s^{*}\right)\left(1-x^{*}\right) \frac{p^{\prime}}{1-p^{\prime}}>\left(1-s^{*}\right)\left(1-x^{*}\right) \frac{p^{\prime}}{1-p^{\prime}}-\mu_{b}-\mu_{p}>s^{*}\left(1-x^{*}\right)=U_{h p}$

which imply that neither believers nor heathens would choose to become producers, a contradiction.

If $p^{\prime}<\frac{s^{*}\left(1-x^{*}\right)+\mu}{\left(1-x^{*}\right)+\mu}$, then we would have

$U_{\mu b}\left(p^{\prime}\right)=\left(1-s^{*}\right)\left(1-x^{*}\right) \frac{p^{\prime}}{1-p^{\prime}}-\mu_{b}<s^{*}\left(1-x^{*}\right)+\mu_{p}=U_{\mu p}$

which implies than no believers can be bandits and all believers must be producers. But then, since the number of believers $\beta \geq \frac{s^{*}\left(1-x^{*}\right)+\mu}{\left(1-x^{*}\right)+\mu}$, we have $\beta>p^{\prime}$ or that the number of believers is greater than the number of producers, a contradiction.

Therefore the equilibrium must be unique in this case as well.

Proof of Proposition 2: Part (i): Note that

$x^{\sigma}=\operatorname{argmax}{ }_{x} U_{\mu p}(x)=[(1-\sigma) s(x)+\sigma s(x+\gamma g)](1-x)+\mu_{p}$

Differentiation of (6) yields

$\frac{\partial U_{\mu p}(x)}{\partial x}=\left[(1-\sigma) s^{\prime}(x)+\sigma s^{\prime}(x+\gamma g)\right](1-x)-[(1-\sigma) s(x)+\sigma s(x+\gamma g)]$

Since $s(x)$ is strictly concave, we have $s^{\prime}(x)>s^{\prime}(x+\gamma g)$ for all $x$ and $\gamma g>0$. Therefore, we have:

$\left[(1-\sigma) s^{\prime}(x)+\sigma s^{\prime}(x+\gamma g)\right]<s^{\prime}(x)$ 
Moreover, since $s(x)<s(x+\gamma g)$ we also have

$[(1-\sigma) s(x)+\sigma s(x+\gamma g)]>s(x)$

The last two inequalities imply

$\frac{\partial U_{\mu p}\left(x^{*}\right)}{\partial x}=\left[(1-\sigma) s^{\prime}\left(x^{*}\right)+\sigma s^{\prime}\left(x^{*}+\gamma g\right)\right]\left(1-x^{*}\right)-\left[(1-\sigma) s\left(x^{*}\right)+\sigma s\left(x^{*}+\gamma g\right)\right]<s^{\prime}\left(x^{*}\right)(1-$ $\left.x^{*}\right)-s\left(x^{*}\right)=0$

with the last equality sign following from the optimality condition of a heathen producer (or a believer producer with $\sigma=0)$. Then, for $x^{\sigma} \in(0,1)$, we must have

$\frac{\partial U_{\mu p}\left(x^{*}\right)}{\partial x}<0=\frac{\partial U_{\mu p}\left(x^{\sigma}\right)}{\partial x}$

Given that $s(x)<0$, we can readily show that $\frac{\partial^{2} U_{\mu p}(x)}{\partial x^{2}}<0$. We must then have $x^{\sigma}<x^{*}$ as stated in the Proposition.

By totally differentiating the first-order condition we can readily show that $x^{\sigma}$ is decreasing in $\sigma$.

Part (ii): The stated properties of $1-x^{\sigma}$ readily follow from the properties of $x^{\sigma}$.

Part (iii): The material payoff of a producer who is a believer is $s\left(x^{\sigma}\right)\left(1-x^{\sigma}\right)$. Then, we have $\frac{\partial s\left(x^{\sigma}\right)\left(1-x^{\sigma}\right)}{\partial \sigma}=\frac{\partial x^{\sigma}}{\partial \sigma} s^{\prime}\left(x^{\sigma}\right)\left(1-x^{\sigma}\right)-s\left(x^{\sigma}\right) \frac{\partial x^{\sigma}}{\partial \sigma}=\frac{\partial x^{\sigma}}{\partial \sigma}\left[s^{\prime}\left(x^{\sigma}\right)\left(1-x^{\sigma}\right)-s\left(x^{\sigma}\right)\right]$

Given that, by part (i) of the Proposition, $\frac{\partial x^{\sigma}}{\partial \sigma}<0$, to that show that the material payoff of a believer producer is decreasing in $\sigma$, it suffices to show that

$$
s^{\prime}\left(x^{\sigma}\right)\left(1-x^{\sigma}\right)-s\left(x^{\sigma}\right)>0
$$

Note that $\frac{\partial U_{\mu p}\left(x^{\sigma}\right)}{\partial x}=0$ implies

$$
\left[(1-\sigma) s^{\prime}\left(x^{\sigma}\right)+\sigma s^{\prime}\left(x^{\sigma}+\gamma g\right)\right]\left(1-x^{\sigma}\right)=(1-\sigma) s\left(x^{\sigma}\right)+\sigma s\left(x^{\sigma}+\gamma g\right)
$$

Given that $s(x)$ is strictly concave, we have $s^{\prime}\left(x^{\sigma}\right)>s^{\prime}\left(x^{\sigma}+\gamma g\right)$ and, therefore, $s^{\prime}\left(x^{\sigma}\right)\left(1-x^{\sigma}\right)>[(1-$ $\left.\sigma) s^{\prime}\left(x^{\sigma}\right)+\sigma s^{\prime}\left(x^{\sigma}+\gamma g\right)\right]\left(1-x^{\sigma}\right)$. Moreover, since $s(x)$ is increasing $(1-\sigma) s\left(x^{\sigma}\right)+\sigma s\left(x^{\sigma}+\gamma g\right)>s\left(x^{\sigma}\right)$. We therefore have $s^{\prime}\left(x^{\sigma}\right)\left(1-x^{\sigma}\right)>s\left(x^{\sigma}\right)$ or that $s^{\prime}\left(x^{\sigma}\right)\left(1-x^{\sigma}\right)-s\left(x^{\sigma}\right)>0$ and

$$
\frac{\partial s\left(x^{\sigma}\right)\left(1-x^{\sigma}\right)}{\partial \sigma}<0
$$

as required. Recall that a heathen producer's material payoff is $s\left(x^{*}\right)\left(1-x^{*}\right)$ where $x^{*}$ maximizes $s(x)(1-x)$. We have already proved that $x^{\sigma} \neq x^{*}$. Hence it follows readily that $s\left(x^{\sigma}\right)\left(1-x^{\sigma}\right)<$ $s\left(x^{*}\right)\left(1-x^{*}\right)$ so that a heathen producer has a higher material payoff than a believer producer.

Proof of Proposition 3: Part (i): We have already shown the derivation of the ruler's payoff function under the assumption that all believers are guards in the main text. It remains to be shown that this yields a higher payoff than hiring some or all heathens for guards and having some or all believers become producers. Let $0 \leq \lambda \leq 1$. Suppose that $\lambda \beta$ believers are guards while 
the rest are producers. Accordingly $g-\lambda \beta$ heathens are guards while the rest divide up between production and banditry. In that case, the number of producers $p^{\prime}$ consists $(1-\lambda) \beta$ believers and $p^{\prime}-(1-\lambda) \beta$ heathens (with the latter receiving a payoff of $\left.\frac{1}{4}\right)$ and the payoff of heathen producers and bandits equalized as below:

$$
\frac{1}{4}=\frac{(1-\lambda) \beta\left(\frac{1+\sigma \gamma g}{2}-\gamma g\right) \frac{1+\sigma \gamma g}{2}+\left(p^{\prime}-(1-\lambda) \beta\right)\left(\frac{1}{2}-\gamma g\right) \frac{1}{2}}{1-p^{\prime}-g}
$$

which yields the following number of producers:

$$
p^{\prime}=\frac{1-g}{2(1-\gamma g)}+\beta \frac{(\lambda-1) \sigma \gamma g(2+\sigma \gamma g-2 \gamma g)}{2(1-\gamma g)}
$$

Note that the number of producers in this case (when some believers become producers instead of guards) is generally lower than number of producers when all believers become guards (derived in the equation before (9)) as the second term is non-positive since $\lambda \leq 1$. This is the greater "leakage" of output, mentioned in the main text, when some believers become producers. The difference in the number of producers is equivalent to having more bandits which translates into lower profits for the ruler. In particular, given $p^{\prime}$, the ruler's payoff is: $\pi_{r}^{\prime}(\beta \in[0, g])=\beta \gamma g \frac{1+\sigma \gamma g}{2}+$ $\left[\frac{1-g}{2(1-\gamma g)}-\beta \frac{\sigma \gamma g(2+\sigma \gamma g-2 \gamma g)}{2(1-\gamma g)}\right] \gamma g \frac{1}{2}-g \frac{1}{4}$

$=\frac{g}{4} \frac{(\gamma-1)}{(1-\gamma g)}+\frac{\beta(\sigma \gamma g)^{2}(\lambda-g \gamma)}{4(1-\gamma g)}$ Observe that the above payoff is strictly increasing in $\lambda$. Hence the optimal level of $\lambda$ is 1 . This gives us the payoff $\pi_{r}(\beta \in[0, g])$ in (10) which is indeed the appropriate one for $\beta \in[0, g]$.

Part (ii): Let $\beta \in\left(g, \beta_{0}\right)$. By the arguments made in the main text and in the proof of part (i), all guards should be believers with the rest becoming producers (as all bandits are heathens and no believer has an incentive to become a bandit when there are sufficiently high numbers of heathens). That is, believer producers number $\beta-g$. Heathens become producers and bandits until the number of believers becomes sufficiently large so that no heathens choose to become producers. This sufficiently large number of believers is $\beta_{0}$ and is derived by equating the payoff of a heathen bandit when all producers are believers to the payoff of a heathen producer or

$$
\frac{\left(\beta_{0}-g\right)\left(\frac{1+\sigma \gamma g}{2}-\gamma g\right) \frac{1+\sigma \gamma g}{2}}{1-\beta_{0}}=\frac{1}{4}
$$

which yields the $\beta_{0}$ stated in the Proposition.

To determine the ruler's payoff function for that range of $\beta$ s', we need to determine the number of producers $p^{\prime \prime}$ and bandits from the following equality of heathen payoffs between bandit and producer:

$$
\frac{(\beta-g)\left(\frac{1+\sigma \gamma g}{2}-\gamma g\right) \frac{1+\sigma \gamma g}{2}+\left[p^{\prime \prime}-(\beta-g)\right]\left(\frac{1}{2}-\gamma g\right) \frac{1}{2}}{1-p^{\prime \prime}-g}=\frac{1}{4}
$$


which yields a $p^{\prime \prime}$ which is analogous to $p^{\prime}$ above:

$$
p^{\prime \prime}=\frac{1-g}{2(1-\gamma g)}-(\beta-g) \frac{\sigma \gamma g((2+\sigma \gamma g-2 \gamma g)}{2(1-\gamma g)}
$$

By using this number of bandits in the ruler's payoff we eventually obtain: $\pi_{r}\left(\beta \in\left(g, \beta_{0}\right)\right)=$ $\left.(\beta-g) \gamma g \frac{1+\sigma \gamma g}{2}+\left[p^{\prime \prime}-(\beta-g)\right]\right] \gamma g \frac{1}{2}-g \frac{1-(\sigma \gamma g)^{2}}{4}$

$=\frac{g}{4} \frac{\left(\gamma-1+(\sigma \gamma g)^{2}\right)}{(1-\gamma g)}-\frac{\beta \sigma^{2}(\gamma g)^{3}}{4(1-\gamma g)}$ which is strcitly decreasing in $\beta$, as stated in the Proposition.

Part (iii): Let $\beta \in\left[\beta_{0}, \beta_{1}\right]$. Over that range of $\beta \mathrm{s}^{\prime}, \beta_{1}$ is defined so that the payoff of a believer producer just equals the payoff of believer bandit. That is,

$$
\frac{\left(\beta_{1}-g\right)\left(\frac{1+\sigma \gamma g}{2}-\gamma g\right) \frac{1+\sigma \gamma g}{2}}{1-\beta_{1}}-\mu_{b}=\frac{(1+\sigma \gamma g)^{2}}{4}+\mu_{p}
$$

where the left-hand side is the believer bandit's payoff and the right-hand side is the believer producer's payoff. (Note that the believer producer's payoff is always greater than $\frac{1}{4}$, the heathen producer's payoff, and therefore heathen bandits must be receiving a higher payoff than $\frac{1}{4}$ as well.) The $\beta_{1}$ defined in the Proposition is the unique solution from this equation. Then, in the range between $\beta_{0}$ and $\beta_{1}$ all bandits are heathens and any new believers become producers, replacing one-for-one the heathen bandits. Thus, as $\beta$ increases, the ruler gains the tax revenue from the extra producers without any cost. The payoff of the ruler is as follows

$$
\pi_{r}\left(\beta \in\left(\beta_{0}, \beta_{1}\right)\right)=(\beta-g) \gamma g \frac{1+\sigma \gamma g}{2}-g \frac{1-(\sigma \gamma g)^{2}}{4}
$$

which is strictly increasing in $\beta$ with a slope of the extra tax revenue $\gamma g \frac{1+\sigma \gamma g}{2}$.

Part (iv): Let $\beta \in\left(\beta_{1}, 1\right]$. Beyond $\beta_{1}$, all extra believers become bandits - every new believer replaces a heathen bandit. That is, over that range the number of producers is fixed at $\beta_{1}-g$ and therefore the profits of the ruler do not change with changes in $\beta$ and are constant at:

$$
\pi_{r}\left(\beta \in\left(\beta_{1}, 1\right]\right)=\left(\beta_{1}-g\right) \gamma g \frac{1+\sigma \gamma g}{2}-g \frac{1-(\sigma \gamma g)^{2}}{4}
$$

Proof of Proposition 4: Parts (i) and (ii): proofs are already discussed in the main text.

Part (iii): Recall that the total payoff of a believer ruler over the second segment $\left(g, \beta_{0}\right)$ is

$\pi_{r \mu}\left(\beta \in\left(g, \beta_{0}\right)\right)=\frac{g}{4} \frac{\left(\gamma-1+(\sigma \gamma g)^{2}\right)}{(1-\gamma g)}+\beta\left[\theta\left(\frac{(1+\sigma \gamma g)^{2}}{4}+\mu-m\right)-\frac{\sigma^{2}(\gamma g)^{3}}{4(1-\gamma g)}\right]$

From above, it is clear that the marginal return on investing in $\beta$ denoted by $M B_{I_{2 \beta}}$ (where the subscript 2 is a reminder that we are working with the second segment of the believer ruler's payoff) is as below.

$$
M B_{I_{2 \beta}}=\frac{\partial \pi_{r \mu}\left(\beta \in\left(g, \beta_{0}\right)\right)}{\partial I_{\beta}}=\beta^{\prime}\left(I_{\beta}\right)\left[\theta\left(\frac{(1+\sigma \gamma g)^{2}}{4}+\mu-m\right)-\frac{\sigma^{2}(\gamma g)^{3}}{4(1-\gamma g)}\right]
$$

From above, it follows that: 


$$
\begin{aligned}
& \frac{\partial M B_{I_{2 \beta}}}{\partial I_{\sigma}}=\beta^{\prime}\left(I_{\beta} .\right) \sigma^{\prime}\left(I_{\sigma}\right) \frac{\gamma g}{2}\left[\theta(1+\sigma \gamma g)-\frac{g^{2} \gamma^{2} \sigma}{(1-g \gamma)}\right] \\
& \frac{\partial M B_{I_{2 \beta}}}{\partial S}=\beta^{\prime}\left(I_{\beta}\right) \gamma^{\prime}(S) \frac{\sigma g}{2}\left[\theta(1+\sigma \gamma g)-\frac{g^{2} \gamma^{2} \sigma+2 g^{2} \gamma^{2} \sigma(1-\gamma g)}{2(1-g \gamma)^{2}}\right]
\end{aligned}
$$

By inspection, it follows that $\frac{\partial M B_{I_{2 \beta}}}{\partial I_{\sigma}}>0$ when $\theta>\frac{g^{2} \gamma^{2} \sigma}{(1-g \gamma)(1+\sigma \gamma g)}\left(\equiv \theta_{1}\right)$. It readily follows that this condition is stronger than Assumption B.

By inspection, it follows that $\frac{\partial M B_{I_{2 \beta}}}{\partial S}>0$ when $\theta>\frac{g^{2} \gamma^{2} \sigma+2 g^{2} \gamma^{2} \sigma(1-\gamma g)}{2(1-g \gamma)^{2}(1+\sigma \gamma g)}\left(\equiv \theta_{2}\right)$. Since $\gamma g<\frac{1}{2}$, it is apparent that $\theta_{2}>\theta_{1}$.

Hence both $\frac{\partial M B_{I_{2 \beta}}}{\partial I_{\sigma}}$ and $\frac{\partial M B_{I_{2 \beta}}}{\partial S}$ are strictly positive when $\theta$ is sufficiently high $\left(\theta>\theta_{2}\right)$.

Part (iv): The total payoff of a believer ruler over the range $\left[\beta_{0}, \beta_{1}\right]$ is

$$
\pi_{r \mu}\left(\beta \in\left[\beta_{0}, \beta_{1}\right]\right)=(\beta-g) \gamma g \frac{1+\sigma \gamma g}{2}-g \frac{1-(\sigma \gamma g)^{2}}{4}+\beta \theta\left(\frac{(1+\sigma \gamma g)^{2}}{4}+\mu-m\right)
$$

The first-order conditions for the investments in $\beta, \sigma$, and $\gamma$ in this segment (denoted by $I_{\beta}^{0}, I_{\sigma}^{0}$, and $S^{0}$ ) are below. (We do not include the first-order condition for investment in $\mu\left(I_{\mu}^{0}\right)$ because it is not complementary to all others.) $\beta^{\prime}\left(I_{\beta}^{0}\right)\left[\gamma g \frac{1+\sigma \gamma g}{2}+\theta\left(\frac{(1+\sigma \gamma g)^{2}}{4}+\mu-m\right)\right]=\frac{\partial c\left(I_{\beta}^{0}, I_{\sigma}^{0}, I_{\mu}^{0}\right)}{\partial I_{\beta}}$

$\sigma^{\prime}\left(I_{\sigma}^{0}\right) \frac{\gamma g}{2}\left[(\beta-g) \gamma g+\sigma \gamma g^{2}+\theta \beta(1+\sigma \gamma g)\right]=\frac{\partial c\left(I_{\beta}^{0}, I_{\sigma}^{0}, I_{\mu}^{0}\right)}{\partial I_{\sigma}}$ $\gamma^{\prime}\left(S^{0}\right) \frac{g}{2}\left[(\beta-g)(1+2 \sigma \gamma g)+\sigma^{2} \gamma g^{2}+\beta \theta \sigma(1+\sigma \gamma g)\right]=1$

The left-hand-side of the first condition is increasing in $\sigma$ and $\gamma$; that of the second condition is increasing in $\beta$ and $\gamma$, and that of the third condition is increasing in $\beta$ and $\sigma$. Therefore, the three investments are complementary to each other as stated in the Proposition.

Part (v): The total payoff of a believer ruler is over the range $\left(\beta_{1}, 1\right]$ is

$$
\pi_{r \mu}\left(\beta \in\left(\beta_{1}, 1\right]\right)=\left(\beta_{1}-g\right) \gamma g \frac{1+\sigma \gamma g}{2}-g \frac{1-(\sigma \gamma g)^{2}}{4}+\beta \theta\left(\frac{(1+\sigma \gamma g)^{2}}{4}+\mu-m\right)
$$

where $\beta_{1}=\frac{(1+g)(1+\sigma \gamma g)^{2}+4 \mu-2 \gamma g^{2}(1+\sigma \gamma g)}{2(1+\sigma \gamma g)^{2}+4 \mu-2 \gamma g(1+\sigma \gamma g)}$

Note that

$$
\frac{\partial \pi_{r \mu}\left(\beta \in\left(\beta_{1}, 1\right]\right)}{\partial \mu}=\frac{\gamma g(1-g)(1+\sigma \gamma g)^{2}(1+\gamma g(\sigma-2))}{2\left[1+2 \mu+\sigma \gamma^{2} g^{2}(\sigma-1)+\gamma g(2 \sigma-1)\right]^{2}}+\beta \theta
$$

Observe that the second term is the same term (from the ruler's psychological payoff) encountered in all other segments of ruler's payoff. Therefore we will have $\frac{\partial \pi_{r \mu}\left(\beta \in\left(\beta_{1}, 1\right]\right)}{\partial \mu}>\frac{\partial \pi_{r \mu}\left(\beta \notin\left(\beta_{1}, 1\right]\right)}{\partial \mu}$ as long as the first term is positive. Since the denominator of the first term is always positive and $\sigma \in(0,1)$, a sufficient condition for the first term to be positive is $g<\frac{1}{\gamma(2-\sigma)}$, which is always true since $\gamma g<\frac{1}{2}<\frac{1}{\gamma(2-\sigma)}$. Hence we have $\frac{\partial \pi_{r \mu}\left(\beta \in\left(\beta_{1}, 1\right]\right)}{\partial \mu}>\frac{\partial \pi_{r \mu}\left(\beta \notin\left(\beta_{1}, 1\right]\right.}{\partial \mu}$ as stated in the Proposition.

Part (vi): This part follows straightforwardly from the observations that for all ranges of $\beta$, $\frac{\partial^{2} \pi_{r \mu}}{\partial \mu \partial \beta}=\theta>0$ and $\beta^{\prime}\left(I_{\beta}\right)$ and $\mu^{\prime}\left(I_{\mu}\right)$ are both strictly positive as well. 


\section{References}

Aghion, P., \& Howitt, P. (1997). Endogenous growth theory. Cambridge, MA: MIT Press.

Akerlof, G. A., \& Kranton, R. E. (2000). Economics and identity. Quarterly Journal of Economics, 115(3), 715-753.

Besley, T., \& Persson, T. (2011). Pillars of prosperity: the political economics of development clusters. Princeton, NJ: Princeton University Press.

Boyd, R. (2017). A different kind of animal: how culture transformed our species. Princeton, NJ: Princeton University Press.

Coşgel, M. M., Histen, M., Miceli, T.J., \& Yıldırım, S. (2018). State and religion over time. Journal of Comparative Economics, 46(1), 20-34.

Cosgel, M. M., \& Miceli, T. J. (2009). State and religion. Journal of Comparative Economics, 37, 402-426.

Creel, H. G. (1949). Confucius and the way. New York: Harper \& Row Publishers.

Cunliffe, B. (2017). By steppe, desert, and ocean: the birth of Eurasi. New York: Oxford University Press.

Dudley, L.M. (1991). The word and the sword: how techniques of information and violence have shaped our world. New York: Wiley-Blackwell.

Ekelund, R., Hebert, R. F., Tollison, R. D., Anderson, G. M., \& Davidson,A. B. (1996). Sacred trust: the medieval church as an economic firm. New York and Oxford: Oxford University Press.

Engineer, M. (1989). Taxes, public good, and the ruling class: an exploration of the territory between Brennan and Buchanan's leviathan and conventional public finance. Public Finance/Finances Publique, 44(1), 19-30.

Findlay, R. (1990). The new political economy: its explanatory power for the LDCs. Economics and Politics, 2, 193-221.

Findlay, R. (1996). Towards a model of territorial expansion and the limits of empire. In Garfinkel, M. R., \& Skaperdas, S. (Eds.), The political economy of conflict and appropriation. New York: Cambridge University Press.

Finer, S. (1997). The history of government, vols 1-3. New York: Oxford University Press.

Fletcher, R. (1997). The barbarian conversion: from Paganism to Christianity. New York: Henry Holt. 
Grossman, H., \& Noh, S. J. (1994). Proprietary public finance and economic welfare. Journal of Public Economics, 53, 187-204.

Henrich, J., Boyd, R., Bowles, S., Camerer, C., Fehr, E., Gintis, H., \& McElreath, R. (2001). In search of homo economicus: behavioral experiments in 15 small-scale societies. American Economic Review, Papers and Proceedings, 91(2), 73-78.

Holland, T. (2005). Persian fire: the first world empire and the struggle for the west. New York: Doubleday.

Iannaccone, L. R. (1998). Introduction to the economics of religion. Journal of Economic Literature, 36(3), 1465-1495.

Iyer, S. (2016). The new economics of religion. Journal of Economic Literature, 54(2), 395-441.

Jaspers, K.(2011 [1949]). Origin and goal of history. New York: Routledge.

Johnson, N. D., \& Koyama, M. (2017). States and economic growth: capacity and constraints. Explorations in Economic History, 64, 1-20.

Kalin, M., \& Sambanis, N. (2018). How to think about social identity. Annual Review of Political Science, 21, 239-257.

Keay, J. (2000). India: a history. New York: Grove Press.

Khaldûn, I. (1994). The Muqaddimah: an introduction to history. Translated from the Arabic by Franz Rosenthal; edited and abridged by N.J. Dawood. Princeton, NJ: Princeton University Press.

Konrad, K. A., \& Qari, S. (2012). The last refuge of a scoundrel? patriotism and tax compliance. Economica, 79, 516-533.

Konrad, K. A. and Skaperdas, S. (1998). Extortion. Economica, 65, 461-77.

Konrad, K. A., \& Skaperdas, S. (2007). Succession rules and leadership rents. Journal of Conflict Resolution, 51(4), 622-645.

Konrad, K. A., \& Skaperdas, S. (2012). The market for protection and the origin of the state. Economic Theory, 50(2), 417-443.

Lane Fox, R. (1986). Pagans and christians. New York: Harper Collins.

Leeson, P. T. (2014). Anarchy unbound: why self-governance works better than your think. New York: Cambridge University Press.

Levi, M. (1988). Of rule and revenue. Berkeley: University of California Press. 
Mann, M. (1986). The sources of social power, vol. 1: from the beginning to 1760 AD. New York: Cambridge University Press.

McBride, M. (2016). A rational choice theory of religious authority. Rationality and Society, 28, 410-438.

McBride, M., Milante, G., \& Skaperdas, S. (2011). Peace and war with endogenous state capacity. Journal of Conflict Resolution, 55(3), 446-468.

McGuire, M. C. \& Olson, M. (1996). The economics of autocracy and majority rule: the invisible hand and the use of force. Journal of Economic Literature, 34, 72-96.

Moselle, B., \& Polak, B. (2001). A model of a predatory state. Journal of Law, Economics, and Organization, 17(1), 1-33.

Myerson, R. B. (2008). The autocrat's credibility problem and foundations of the constitutional state. American Political Science Review, 102(1), 125-139.

Norenzayan, A. (2013). Big gods: how religion transformed cooperation and conflict. Princeton, NJ: Princeton University Press.

North, D. C., Wallis, J. J., \& Weingast, B. R. (2009). Violence and social orders: a conceptual framework for interpreting recorded human history. New York: Cambridge University Press.

Olson, M. (1993). Dictatorship, democracy, and development. American Political Science Review, $87(3), 567-76$.

Raskovich, A. (1996). You shall have no other gods besides me: a legal-economic analysis of the rise of Yahweh. Journal of Institutional and Theoretical Economics, 152(3), 449-471.

Robinson, J. A. (1997). When is a state predatory? Working Paper.

Salter, A. W., \& Young, A. T. (2018). Medieval representative assemblies: collective action and the antecedents of limited government. Constitutional Political Economy, 29(2), 171-192.

Sambanis, N., \& Shayo, M. (2013). Social identification and ethnic conflict. American Political Science Review, 107(2), 294-325.

Sambanis, N., Skaperdas, S., \& Wohlforth, W. (2015). Nation-building through war. American Political Science Review, 109(2), 279-296.

Shayo, M. (2009). A model of social identity with an application to political economy: nation, class, and redistribution. American Political Science Review, 103(2), 147-174. 
Skaperdas, S. (2001). The political economy of organized crime: providing protection when the state does not. Economics of Governance, 2, 173-202.

Skaperdas, S. (2014). Proprietary public finance: its emergence and evolution out of anarchy. In Dominguez-Vazquez, J., \& Winer, S. (Eds.), Coercion and social welfare in public finance: economic and political dimensions. New York: Cambridge University Press.

Tajfel, H. (1981). Human groups and social categories: studies in social psychology. Cambridge, UK: Cambridge university Press.

Vahabi, M. (2016a). The political economy of predation: manhunting and the economics of escape. New York: Cambridge University Press.

Vahabi, M. (2016b). A positive theory of the predatory state. Public Choice, 168(3-4), 153-175.

Whitehouse, H., François, P., Savage, P.E., Currie, T.E., Feeney, K.C., Cioni, E., Purcell, R., Ross, R.M., Larson, J., Baines, J., ter Haar, B., Covey, A., \& Turchin, P. (2019). Complex societies precede moralizing gods throughout world history. Nature, 568, 226-229.

Wimmer, A. (2018). Nation building: why some countries come together while others fall apart. Princeton, NJ: Princeton University Press.

Wintrobe, R. (1998). The political economy of dictatorship. New York: Cambridge University Press. 
Range of $\beta$ : Believers $(\beta)$ become:

$[0, g]$

$\left(g, \beta_{0}\right)$

$\left[\beta_{0}, \beta_{1}\right]$

$\left(\beta_{1}, 1\right]$
All guards

Guards and producers

Guards and producers

Guards, producers, and bandits
Heathens $(1-\beta)$ become:

Guards, producers, bandits

Producers and bandits

All bandits

All bandits

Table 1: Population's occupational choice 
Figure 1: Production under anarchy

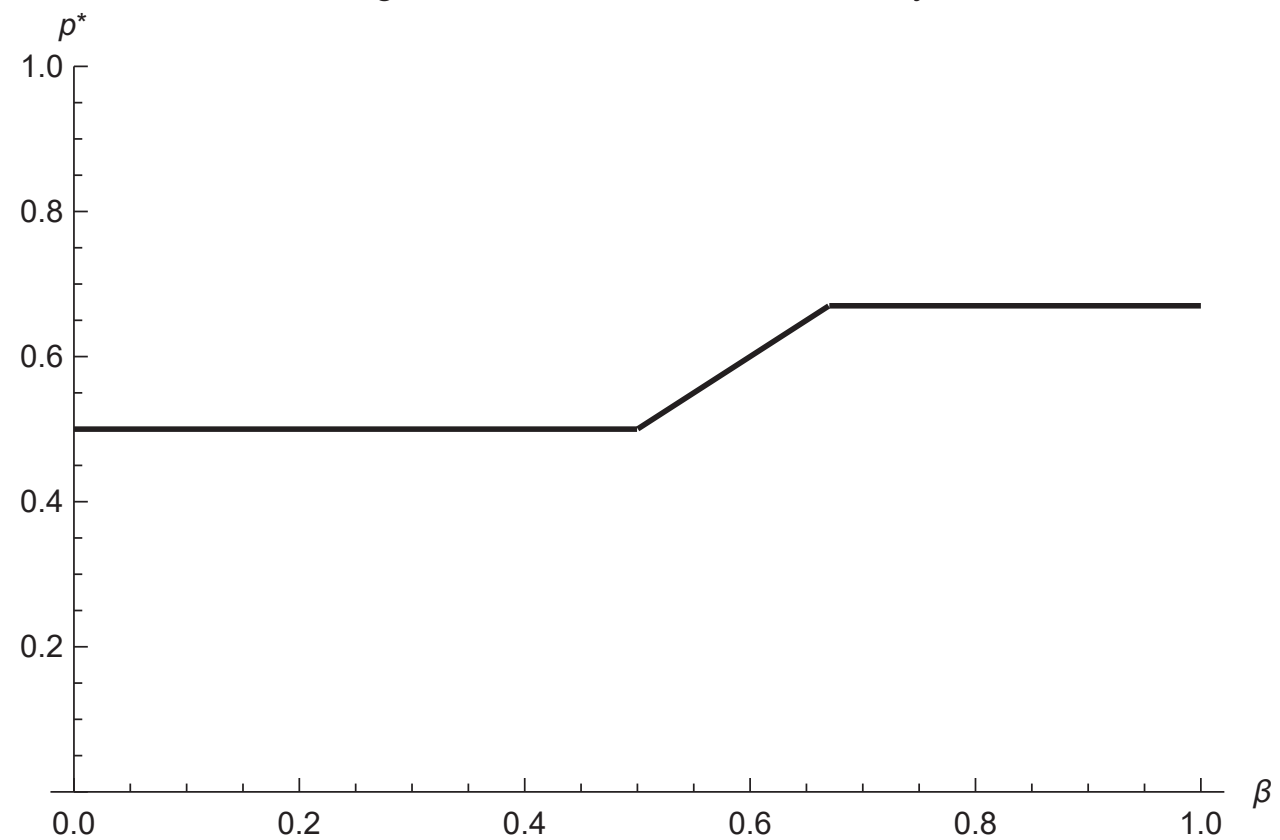


Figure 2: Ruler's profits

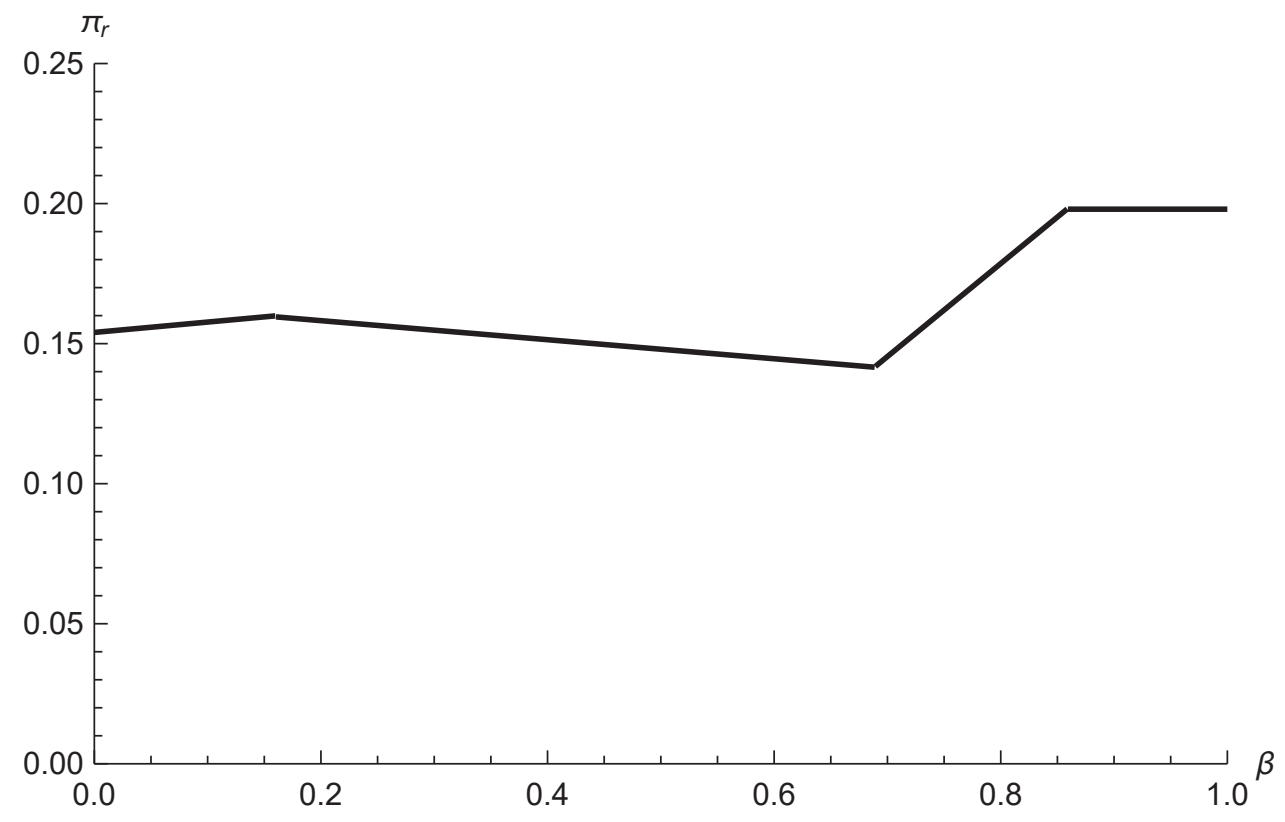


Figure 3: Believer ruler's welfare

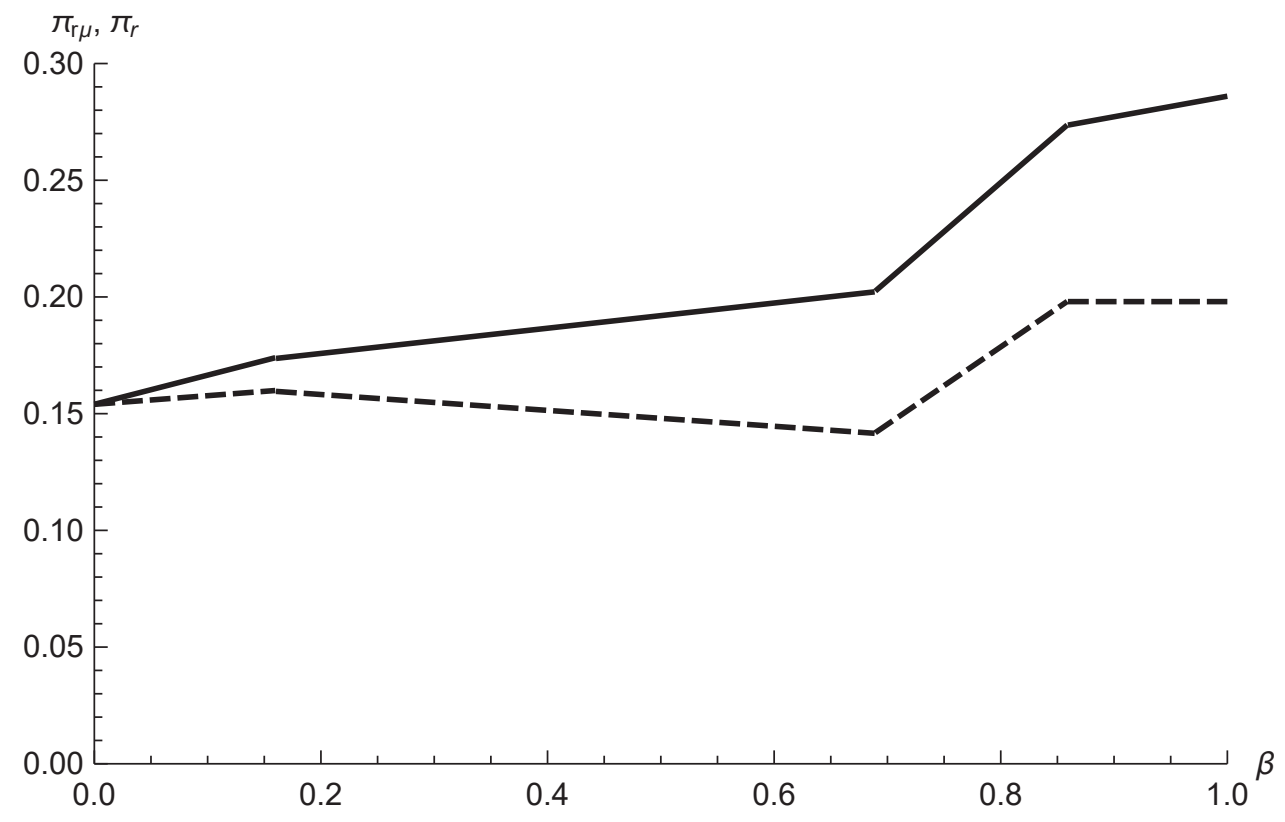

